
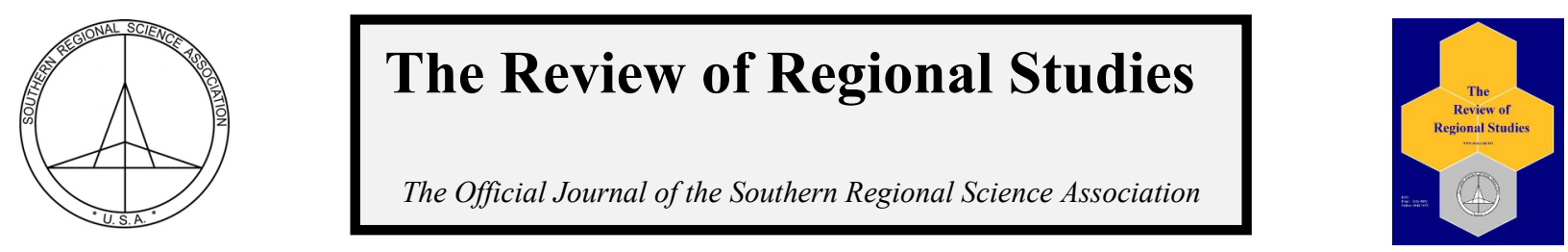

\title{
The Determinants of Credit Allocations in a Market-based Trading System: Evidence from the RECLAIM Program*
}

\author{
Antonio M. Bento ${ }^{\mathrm{a}}$, Emeric Henry ${ }^{\mathrm{b}}$, and Scott E. Lowe ${ }^{\mathrm{c}}$ \\ ${ }^{a}$ Charles H. Dyson School of Applied Economics and Management, Cornell University, USA \\ ${ }^{b}$ Department of Economics, Sciences Po., France \\ ${ }^{c}$ Department of Economics, Boise State University, USA
}

\begin{abstract}
This paper examines the determinants of emission credit allocations under the Regional Clean Air Incentives Market (RECLAIM) - a program aimed at reducing nitrogen oxides $\left(\mathrm{NO}_{\mathrm{X}}\right)$ and sulfur oxides $\left(\mathrm{SO}_{\mathrm{X}}\right)$ - in the greater Los Angeles area. Our results suggest that deviations in the allocation of emission credits can be systematically explained by firm-level factors and the location of the facility. Our results also indicate that deviations in the allocation of emission credits may have been made in an attempt to regulate toxics, and that certain industries were protected in the early stages of the program.

Keywords: Regional Clean Air Incentives Market (RECLAIM); air pollution; $\mathrm{NO}_{\mathrm{x}}$; distributional impacts; marketbased permits
\end{abstract}

JEL Codes: Q52, Q53, Q58

\section{INTRODUCTION}

In October of 1993, the South Coast Air Quality Management District (SCAQMD) of California adopted the Regional Clean Air Incentives Market (RECLAIM) program, which set an emissions cap and declining balance for many of the largest facilities emitting nitrogen oxides $\left(\mathrm{NO}_{\mathrm{X}}\right)$ and sulfur oxides $\left(\mathrm{SO}_{\mathrm{X}}\right)$ in the south coast air basin. RECLAIM included 374 participants in its $\mathrm{NO}_{\mathrm{X}}$ market and 40 participants in its $\mathrm{SO}_{\mathrm{X}}$ market. Motivated by theoretical arguments and growing empirical evidence that market-based instruments are substantially more cost-effective than traditional command-and-control regulations, the program was designed to provide industry with the flexibility to decide how to reduce emissions and advance pollution control techniques (USEPA, 2002). ${ }^{1}$

\footnotetext{
${ }^{*}$ We are grateful for the useful comments and suggestions received from seminar participants at Camp Resources, the Western Economic Association, the U.C. Santa Barbara Occasional Environmental Economics Conference, the Greening California Conference, and three anonymous referees. Lowe received funding from the University of California Toxic Substances Research and Teaching Program.

Bento is Associate Professor of Economics at Cornell University, Ithaca, NY, USA. Henry is Associate Professor of Economics at Sciences Po., Paris, France. Lowe is Associate Professor of Economics at Boise State University, Boise, ID, USA. Corresponding Author: S.E. Lowe E-mail: scottlowe@boisestate.edu

${ }^{1}$ Since the early 1970s, economists have advocated for the use of market-based policies, such as emissions taxes or tradable permits (Weitzman, 1974; Dales, 1968). Early work by Baumol and Oates (1971) and Montgomery (1972) demonstrated that market-based permit systems have the potential of minimizing the cost associated with attaining a target of emissions reductions. Additional studies include the work by Atkinson and Lewis (1974), Seskin et al. (1983), McGartland and Oates (1985), Hahn and Hester (1989), and Tietenberg (1990), which present empirical magnitudes for market-based permit systems relative to the command and control policies. More recently Fowlie et al. (2012) have analyzed the equity concerns of cap and trade programs,
} 
At the beginning of the RECLAIM program, a key issue addressed by the SCAQMD was the definition of the rule that would allocate emission credits amongst different facilities (Johnson and Pekelney, 1996). $\mathrm{NO}_{\mathrm{X}}$ and $\mathrm{SO}_{\mathrm{X}}$ credit allocations were issued to RECLAIM facilities based on their historical activity levels and applicable emission control levels specified in the rules that the RECLAIM program subsumed. However, it appears that the regulators, using their discretionary power, systematically deviated from historical emissions when allocating the RECLAIM emission credits. Such deviations may not be all that surprising, as many pollutionrelated industries have political influence sufficient to block policies that would harm their profits. Indeed, as discussed in Bovenberg et al. (2005, 2008), a politically realistic approach to environmental policy may require avoiding significant profit-losses to these industries. ${ }^{2}$

The observed deviations in allocations of RECLAIM emission credits relative to the historical emission levels may not affect the overall control costs, and thus the efficiency, of the program. Montgomery (1972) proved that, in theory, the cost-effective allocation of control responsibility in a market based permit system is independent of the initial allocation of permits. In this case the trading mechanism guarantees that the overall costs of control of emissions are minimized. However, in the presence of certain market conditions, such as transaction costs, market power, or future price uncertainty, the independence of cost-effectiveness and initial allocation is not guaranteed (Hahn and Stavins, 2011).

Stavins (1995) demonstrated that transaction costs can reduce trading levels and increase abatement costs. In the presence of certain transaction costs, equilibrium permit allocations and hence aggregate control costs are sensitive to initial permit distributions, providing an efficiency justification for politicians' typical focus on initial allocation. There is every indication that SCAQMD officials were aware that there would be significant transaction costs in the early phase of the RECLAIM program. In addition to the newness of the program, RECLAIM officials anticipated that uncertainties surrounding compliance needs and the lack of an effective brokerage service would lead to reduced trading activities (Prager et al., 1996; Cone, 1993). In an analysis of RECLAIM participants' trading behaviors, Gangadharan (2000) found that in the early years of the program, transaction costs led to a $32 \%$ decrease in the likelihood that a RECLAIM firm would participate in the trading market.

Similarly, there is increasing evidence that environmental justice groups have been effective in influencing their local environmental policy setting (Oates and Portney, 2003). Solomon and Lee (2000) note that pollution emissions trading systems continue to be criticized by environmental organizations for the creation of toxic hotspots. Yet, to date, there is very little empirical evidence of the magnitudes of the potential deviations of allocations of emission credits relative to historical emissions as well as the determinants of these deviations. This paper fills this important gap in the literature.

\footnotetext{
and Fowlie and Perloff (2008) have addressed the endogeneity of permit allocations with observed pollution emissions in cap and trade programs.

${ }^{2}$ Bovenberg et al. (2005) examine how the efficiency cost of emissions permits change when the program is designed to insulate profits. The relative increase in efficiency cost is sensitive to the extent of pollution abatement. As the required level of abatement increases, the costs associated with the abatement decrease, relative to the other efficiency costs of control. Bovenberg et al. (2008) show that when extensive pollution abatement is required, price-based instruments are more cost-effective than command and control policies because of their overall intrinsic abatement costs (i.e., higher economic efficiencies with regards to pollution abatement).
}

(C) Southern Regional Science Association 2013. 
The purpose of this paper is to examine the key determinants and distributional impacts of credit allocations in the RECLAIM program. We examine the deviation of allocation of emission credits in 1994, 2000, and 2003 from historical emission levels, and provide suggestive evidence of the factors that may have contributed to these deviations. Specifically, we focus on the following questions: Were regulators sensitive to environmental justice lobbies and did they use the RECLAIM program, at least in the short run when the expectation for emissions trading was low, to not only control emissions of $\mathrm{NO}_{\mathrm{X}}$ and $\mathrm{SO}_{\mathrm{X}}$ but also regulate toxics? Toxics, in particular their spatial concentration in hotspots and their disproportionate impact on minorities, have been a major concern of environmental lobbies (SCAQMD, 2000a; 2000b) ${ }^{3}$ and historically they have been harder to regulate, given the diversity of sources and their localized effects. ${ }^{4}$ In addition, we look at the impact of industry employment levels and size on the allocation of emission credits. ${ }^{5}$

There is an extensive literature that examines how the behavior of governmental agencies is influenced by interest groups. ${ }^{6}$ In the context of environmental policy, for example, Cropper et al. (1992) find that regulators do take into account both special interests and general welfare when setting environmental standards for pesticide regulation. Sigman (2001) empirically explored bureaucratic priorities by studying the Superfund program. Her work provides little evidence that the EPA prioritizes sites according to their harms and suggests instead that concentrated private interests, such as liable parties and local communities, play an important role in the EPA's priorities. More recently, Cook (2010) and Rabe (2010) analyze a number of proposed climate change-mitigating policy options in the United States, and identify the potential influence of powerful industrial lobbies (and their rent-seeking behaviors) as a detractor for cap and trade regulatory systems with auctioned emissions permits. Ellerman et al. (2007) and Raymond (2003) identify lobbying pressures and prior-use norms as factors that influence the design and structure of cap and trade systems. Raymond (2003) discusses the presence of both self-interest behaviors by legislators as well as equity norms in playing a role in the allocation of $\mathrm{SO}_{2}$ allowances under the Acid Rain Title of the 1990 Clean Air Act Amendments. Closely related to our study, Joskow and Schmalensee (1998) examine how Congress, influenced by the executive branch and various special interests, distributed $\mathrm{SO}_{2}$ allowances among electric utilities in the process of crafting acid rain legislation.

\footnotetext{
${ }^{3}$ In some of our interviews with SCAQMD officials, it was pointed out to us that the agency made serious attempts to include some toxics in the design of the RECLAIM program, in part because the ultimate goal of the program was to reduce ozone. Because of the complications associated with regulating toxics directly, the agency opted to focus on $\mathrm{NO}_{\mathrm{X}}$ and $\mathrm{SO}_{\mathrm{X}}$. However, to the extent that emissions of $\mathrm{NO}_{\mathrm{X}}$ and $\mathrm{SO}_{\mathrm{X}}$ are corrected with toxics, by regulating $\mathrm{NO}_{\mathrm{X}}$ the agency hoped to indirectly address some of the toxics concerns as well.

${ }^{4}$ There is a well-developed theoretical literature on ambient market-based permit systems that would be capable of accounting for hotspots, beginning with Montgomery (1972). The difficulties associated with implementing an ambient permit system are

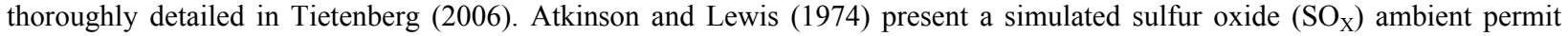
system that is cost-effective when compared to command and control systems, but to our knowledge no ambient permit-based system has ever been implemented. Chicago implemented a market-based system for volatile organic pollutants (VOCs), but simultaneously maintained its existing command and control system, to control for VOC hotspots (Kosobud et al., 2008). Kosobud et al., (2004) estimate that implementing an ambient permit system that also controls for hotspots could increase pollution control costs by 40 percent.

${ }^{5}$ For a detailed discussion of the interplay between jobs and the environment, see: Morgenstern et al. (2002) and Berman and Bui (2001).

${ }^{6}$ For excellent survey of the literature on the political economy of environmental regulation, see Stavins (2004).
} 
While these studies have clearly advanced our understanding of the behavior of political institutions and the setting of environmental policies, several key features distinguish our work from previous literature. First, our work is the first to examine the behavior of a regional regulatory agency. This is important to the extent that locally-elected officials are likely to be held more accountable for their actions by the local residents that elected them and the local facilities they regulate.

Second, the heterogeneity of facilities in this study is much greater than in Joskow and Schmalensee (1998), the prior study most closely related to ours. The heterogeneity of regulated facilities allows us to examine very important public policy questions, such as whether agencies systematically penalize facilities based on specific characteristics such as SIC or size. It also allows us to test whether identical facilities receive different treatments based on their spatial location, therefore highlighting the potential distributional costs associated with delegation of regulatory authority.

Third, because of the spatial features of our empirical strategy, we are able to ask whether a facility's initial $\mathrm{NO}_{\mathrm{X}}$ allocation is influenced by its own emissions (of both $\mathrm{NO}_{\mathrm{X}}$ and Toxics) as well as the characteristics of neighboring facilities. Similarly, we examine whether a facility's location in a toxics hotspot affects the allocation of emission credits for that facility. None of these kinds of spatial considerations were central to previous literature on the political economy of environmental policy, yet spatial aspects are clearly central to the design of environmental policy.

We combine data on the individual facility characteristics, historical emissions, and initial allocations of $\mathrm{NO}_{\mathrm{X}}$ credits to estimate spatial econometric models of the difference between emission credits allocation and historical emissions in 1994, 2000, and 2003. Our empirical results provide evidence that the employment to $\mathrm{NO}_{\mathrm{X}}$ emissions ratio and the toxics to $\mathrm{NO}_{\mathrm{X}}$ emissions ratio determine the deviations in $\mathrm{NO}_{\mathrm{X}}$ credit allocations. In addition, our empirical work also suggests that the coastal location of the facility and facility size impacts the deviations in credit allocations.

When examining the factors that influence the deviations of $\mathrm{NO}_{\mathrm{X}}$ credit allocations over time, we note two important and somewhat intriguing results. First, it appears that regulators used the RECLAIM program to regulate toxics in the short run, when there were transactions costs present. In the absence of trade, these allocations are really just command and control regulations and indeed force facilities to reduce their toxic emissions. Over time, with the removal of the barriers to trade and the installation of abatement technologies, the regulating agency loses its ability to control toxics emissions and reduces its likelihood of preventing toxic hotspots. Second, we find that the regulator over-allocated $\mathrm{NO}_{\mathrm{X}}$ emission credits to electric utilities at the beginning of the program, relative to their historical emission levels. However, these same electric utilities are asked to contribute to their share of $\mathrm{NO}_{\mathrm{X}}$ reductions at later years of the program. These results are consistent with the findings of Joskow and Schmalensee (1998) that show that in the early years of the Acid Rain program, more sulfur dioxide emission credits were allocated to higher emission electric utilities, and that these same facilities were allocated fewer allowances in the later years of the program. ${ }^{7}$

\footnotetext{
${ }^{7}$ Joskow and Schmalensee (1998) argue that the differences in allocations were designed to give the dirtier electric utilities more time to install costly abatement technologies.
}

(C) Southern Regional Science Association 2013. 
The remainder of the paper is organized as follows: In Section 2 we present a brief overview of the RECLAIM program; In Section 3 we introduce the data and discuss the empirical model; Section 4 presents the results, and section 5 offers some conclusions.

\section{BRIEF OVERVIEW OF THE RECLAIM PROGRAM}

In this section, we briefly describe two key features of the RECLAIM program relevant to our work: the design of the program itself, and the rule that justified the allocation of RECLAIM trading credits (RTCs) for $\mathrm{NO}_{\mathrm{X}}$.

\subsection{The South Coast Air Quality Management District and the RECLAIM Program}

The greater Los Angeles area has a long history of poor air quality and of using innovative approaches to improve air quality. The primary contributor to the poor air quality in the greater Los Angeles area is ozone pollution. Ozone is produced when gaseous precursors $\mathrm{NO}_{\mathrm{X}}$ and Volatile Organic Compounds (VOCs) - react in the presence of sunlight. As a pollutant, elevated levels of ozone have been shown to cause lung damage, chronic lung disease, and respiratory infections (Peters et al., 1999). Over the 1989 to 1993 timeframe the counties in the greater Los Angeles area experienced the most extreme violations of air quality standards in the nation: the Federal one-hour standard for ozone was violated for an average of 137 days per year, the Federal eight-hour standard was violated for an average of 171 days per year, and the Los Angeles area had an average of 41 stage-one ozone episodes per year ${ }^{8}$ (SCAQMD, 2006).

In 1977, the air pollution control districts in the four counties in the greater Los Angeles area united to form the SCAQMD. The SCAQMD, which includes all of Orange County and the majority portions of Los Angeles, Riverside, and San Bernardino Counties, is responsible for implementing and enforcing air pollution regulations across all of the stationary sources in the four-county area. The SCAQMD currently monitors over 30,000 facilities, in an area of approximately 11,000 square miles, with a population of over 16 million people (USEPA, 2006; SCAQMD, 2008).

In October of 1993 the SCAQMD implemented the RECLAIM program, a cap and trade system designed to reduce the level smog-forming emissions in the SCAQMD by reducing the emissions of $\mathrm{NO}_{\mathrm{X}}$ and $\mathrm{SO}_{\mathrm{X}}$. The RECLAIM program included the largest stationary emitters of $\mathrm{NO}_{\mathrm{X}}$ and $\mathrm{SO}_{\mathrm{X}}$ in the SCAQMD, and had a goal of reducing the total $\mathrm{NO}_{\mathrm{X}}$ emissions by $75 \%$ and the total $\mathrm{SO}_{\mathrm{X}}$ emissions by $60 \%$ between 1994 and 2003 (USEPA, 2006). Facilities in the SCAQMD were required to participate in the RECLAIM program if they had $\mathrm{NO}_{\mathrm{X}}$ or $\mathrm{SO}_{\mathrm{X}}$ emissions that were greater than four tons in 1990 or any subsequent year. ${ }^{9}$ In the design stages of the program, 390 facilities were targeted for inclusion in the $\mathrm{NO}_{\mathrm{X}}$ trading program, and 41 in the $\mathrm{SO}_{\mathrm{X}}$ trading program. At the beginning of the trading program in 1994, $\mathrm{NO}_{\mathrm{X}} \mathrm{RTCs}$ were allocated to 374 facilities, and $\mathrm{SO}_{\mathrm{X}}$ RTCs were allocated to 40 facilities.

\footnotetext{
${ }^{8}$ A stage-one episode occurs when the one hour ambient concentration of Ozone is greater than 0.20 ppm (or $167 \%$ of the Federal 1 hour standard). At this level, most will experience adverse health effects, including shortness of breath, and all sensitive populations, including the young and the elderly, are advised to stay indoors.

${ }^{9}$ Certain facilities with emissions greater than four tons were exempted from the RECLAIM program, including police and fire fighting facilities, hospitals, prisons, publicly-owned municipal waste-to-energy facilities, and all potable water delivery operations (SCAQMD, 1993b).
} 
In the initial design of the RECLAIM program there was an attempt to include facilities that emit VOCs into the trading program. VOCs, many of which are regulated separately as air toxics, are organic gases that react with sunlight to form ozone. The major stationary sources of VOCs include dry cleaners, degreasing and coating operations, petroleum refining and oil and gas extraction. The SCAQMD intended to include an additional 2,000 VOC emitting facilities in its RECLAIM trading framework (USEPA, 2001). Due to difficulties in calculating VOC emissions, the hetereogeneity of VOC sources, and resistance from industry, the SCAQMD removed the VOCs from the trading framework before the program was adopted ${ }^{10}$ (USEPA 2001).

SCAQMD regulators were also concerned with the potential employment impacts of the RECLAIM program. California state law required a socioeconomic analysis of any new air quality rules, and the California Health and Safety Code (1993) mandated that any new air quality rules must not produce a greater loss of jobs than the command and control rules that they subsume. According to a review of the policy alternatives considered for the RECLAIM program, the projected job losses attributed to the RECLAIM program were negative in the first three years of the program, and were projected to be less than 4 hundredths of a percent of the total employment base in the SCAQMD by 1999 (Johnson and Pekelney, 1996). In a later study, Berman and Bui (2001) found that there were almost no employment effects in the SCAQMD due to environmental regulations. ${ }^{11}$

Each facility that participated in the RECLAIM program was designated as either an "inland" or a "coastal" facility, depending on its location. In general, the more severe ambient air quality conditions occur in the inland areas of the SCAQMD, and the most prevalent direction of atmospheric pollution transport is from the coastal to the inland areas. By restricting the trade of credits from inland facilities to coastal facilities, the Inland/Coastal designation limits the transfer of emissions from the downwind locations to the upwind locations. ${ }^{12}$

\subsection{Initial Allocation of RECLAIM Trading Credits}

At the outset of the RECLAIM program, each facility in the program was allocated a unique volume of RTCs, measured in pounds of $\mathrm{NO}_{\mathrm{X}}$ or SOX, for each of the 1994 through 2010 compliance years. Therefore, as of 1994, each RECLAIM facility knew exactly how many RTCs they would be allocated for each year of the program. The aggregate RTC cap for the facilities that participated in the program was designed to decrease from 36,781 tons of $\mathrm{NO}_{\mathrm{X}}$ in 1994 to 9,216 tons (a 75\% reduction) in 2003, and to remain constant from 2003 on. This reduction was consistent with the air quality standards that the RECLAIM cap and trade system subsumed (USEPA, 1995). In order to assure that future emissions goals would be met, any new facilities

\footnotetext{
${ }^{10}$ In the years that followed the implementation of the RECLAIM program, several proposals related to regulating VOCs with a cap and trade system were brought before the SCAQMD Governing Board, none of which were ever implemented (EPA, 2001).

11 Berman and Bui (2001) attribute the lack of an employment effect to three potential causes: the regulations apply disproportionately to the capital-intensive plants that have low employment levels; the plants primarily sell to local markets where their competitors face the same environmental regulations; and the increased need for abatement complements employment.

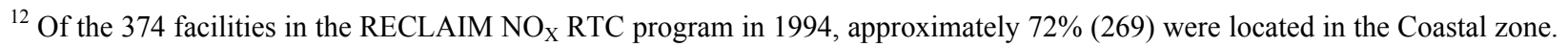
Under the Coastal/Inland classification, Coastal facilities could only acquire $\mathrm{NO}_{\mathrm{X}}$ or $\mathrm{SO}_{\mathrm{X}} \mathrm{RTCs}$ from other Coastal facilities, whereas Inland facilities could acquire RTCs from either Coastal or Inland facilities (Johnson and Pekelney, 1996).
} 
that entered the SCAQMD that were also subject to the RECLAIM program were required to purchase RTCs from existing RECLAIM facilities.

The RECLAIM program was designed such that RTCs could be traded to other facilities within the RECLAIM program, but were only valid for the compliance year and cycle for which they were assigned - no banking of RTCs was allowed. RTCs were assigned to one of two twelve-month staggered cycles in order to avoid problems with price volatility that might occur at the very end of an annual compliance period (Johnson and Pekelney, 1996). RECLAIM facilities were allowed to trade future RTCs, but these futures could only be used in the year/cycle for which they were initially assigned.

At the beginning of the RECLAIM program, a key issue addressed by the SCAQMD was the definition of the rule that would determine the volume of RTCs allocated to the different facilities (Johnson and Pekelney, 1996). The methodology used by the SCAQMD to allocate RTCs is set out in Rule 2002 of the SCAQMD. RTCs were grandfathered to the RECLAIM facilities based on their historical throughput (fuel use), emission factors, prior credits and offsets. ${ }^{13}$ Because there was some historical variability in emissions levels, the throughput year that was used for each facility was based on the maximum emissions year from 1989 to 1992. The 1989 to 1992 period was chosen in order to arrive at an initial allocation that would reflect a recession-neutral baseline year (Prager et al., 1996).

The fuel value for each RECLAIM facility was then multiplied by technology-specific emissions factors (EMSs) to arrive at a $\mathrm{NO}_{\mathrm{X}}$ or $\mathrm{SO}_{\mathrm{X}} \mathrm{RTC}$ allocation, measured in pounds. The EMSs for each facility vary depending on the technology that that facility has installed and were based on existing regulations and the "reasonably available control technology" rules that the RECLAIM program subsumed (USEPA, 1995). For each technology, starting and ending EMSs were determined by the SCAQMD; Rule 2002 specifies that approximately 203 different EMSs were used to determine the 1994 RTC allocation, over $65 \%$ of which were based on proprietary values reported by the individual facilities (SCAQMD, 1993a). The use of EMSs to assign RTCs is convenient because many of the facilities in the RECLAIM program don't have continuous emissions monitoring equipment installed. ${ }^{14}$ Therefore, the past, current and future emissions levels are estimates, based on the technology and volume of fuel that the facility uses.

The 1994, 2000, and 2003 allocation years are particularly important for our analysis. The 1994 allocation is not only the starting RTC allocation for each facility, but it also reflects the severity of the abatement that each facility must make relative to their historical emissions levels. SCAQMD officials anticipated that the RECLAIM trading market would be slow in the initial years of the program (Prager et al., 1996; Cone, 1993). In the first year of the RECLAIM program, only $45 \mathrm{NO}_{\mathrm{X}}$ RTC trades were completed-including trades for future RTCs. The SCAQMD (1998) indicates that these 45 trades accounted for 2,210 tons of $\mathrm{NO}_{\mathrm{X}}$ RTCs. If high transactions costs existed in the RECLAIM trading market during the first few years of the program, then the initial allocations of RTCs could potentially disadvantage those facilities that

\footnotetext{
${ }^{13}$ The RTCs were allocated at zero-cost to the RECLAIM facilities.

${ }^{14}$ The cost of installing and maintaining continuous emission monitoring equipment is high, and the SCAQMD mandates that only the largest $\mathrm{NO}_{\mathrm{X}}$ and $\mathrm{SO}_{\mathrm{X}}$ emitters have continuous emissions monitors installed and certified. As of 1996, only 86 facilities in the SCAQMD had continuous emissions monitors in place (SCAQMD, 1998).
} 
needed access to additional RTCs. In the absence of available RTCs, those facilities in need would be forced to violate the rules of the program, alter their production processes, or move their polluting activities outside of the SCAQMD. ${ }^{15}$

Like the $1994 \mathrm{NO}_{\mathrm{X}} \mathrm{RTC}$ allocation year, the $2000 \mathrm{NO}_{\mathrm{X}}$ RTCs allocation year was calculated using a similar process to the 1994 allocation year: Facility-specific, technology-based EMSs were multiplied by the historical throughput values. ${ }^{16}$ The year 2000 RTC allocation, once determined, also defined the 1995 through 1999 year RTC allocations, since the allocation for each of these years was a facility-specific, straight-line depreciation between the 1994 year allocation and the 2000 year allocation. The significance of the $2000 \mathrm{NO}_{\mathrm{X}} \mathrm{RTC}$ allocation is again rooted in the potential for discretionary regulatory power. Not only does it provide the regulator with a second opportunity to penalize certain firms in the allocation of RTCs, but it also provides the regulator with the ability to reward the firms that received a more severe initial 1994 RTC allocation with a more lenient follow-up depreciation schedule.

The 2003 RTC allocation is included because it reflects the total pollution reduction that the RECLAIM cap-and-trade program will generate. The year 2001, 2002, and $2003 \mathrm{NO}_{\mathrm{X}} \mathrm{RTC}$ allocation levels are facility-specific, but they decline at a constant rate (from the 2000 RTC allocation) for all facilities. ${ }^{17}$

\section{DATA AND ECONOMETRIC MODEL}

To implement our analysis, we combine facility-level data on historical $\mathrm{NO}_{\mathrm{X}}$ emissions, the allocation of $\mathrm{NO}_{\mathrm{X}}$ RTCs for the 1994, 2000 and 2003 emission years, and industry and facility characteristics. This section describes the data sources, presents summary statistics on the different industrial groups in the RECLAIM program, and presents the empirical model.

\subsection{RECLAIM Trading Credits}

The RECLAIM Trading Credit data were obtained directly from the SCAQMD through a public records request. The $\mathrm{NO}_{\mathrm{X}} \mathrm{RTC}$ database includes the yearly allocations, RTC trades, retirement of RTCs, as well as any adjustments to the annual allocations for every facility that participates in the RECLAIM program. For each facility in the RECLAIM program, we were able to obtain from this database the location of the facility, the SIC category of the facility, as well as the 1994, 2000, and $2003 \mathrm{NO}_{\mathrm{X}}$ RTC allocations, all assigned prior to the start date of the program. ${ }^{18}$ The four-digit SIC assigned to each facility was further reduced to a two-digit SIC code, representing the "major" industrial segments, per the United States Economic Census. The location of the facility indicates whether it falls in the Coastal or Inland trading zone.

\footnotetext{
${ }^{15}$ On average, facilities in the RECLAIM NO trading market were allocated more RTCs at the start of the program than were used. (EPA, 2006) The fact that $\mathrm{NO}_{\mathrm{X}}$ RTCs could not be banked, yet trading activity levels were low for both completed trades and sell offers, is indicative of the ineffectiveness of the trading market in the early years of the RECLAIM program.

16 The 2000 RTC credit allocations were based on EMSs that determined the "technologically feasible abatement volume" for each facility in the RECLAIM program (Schubert and Zerlauth, 1999).

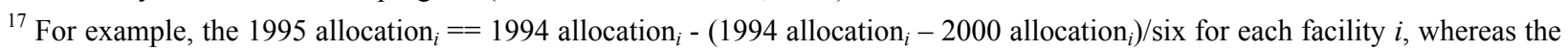
2001 allocation $_{i}==2000$ allocation $_{i} * X$, where $X$ is constant across all facilities (and is equal to $\sim 0.91$ for the 2001 allocation, and $\sim 0.82$ for the 2002 allocation).

18 The SCAQMD reports the $\mathrm{NO}_{\mathrm{X}}$ RTC credit allocations in pounds, but for convenience and in order to coincide with the California Air Resources Board emissions inventory, we have converted these allocations to short tons (2000 lbs).
} 


\subsection{Additional Data: Historical $\mathrm{NO}_{\mathrm{X}}$ Emissions, Revenue, Employment, and Toxics Emissions}

We supplement the data on $\mathrm{NO}_{\mathrm{X}} \mathrm{RTC}$ allocations with additional relevant data, reflecting the need to capture other determinants of the deviations in allocation. Since all of the fuel values and a majority of the technology-specific emissions factors that the SCAQMD used to assign $\mathrm{NO}_{\mathrm{X}}$ RTCs are proprietary, we rely on the facility-level reporting of $\mathrm{NO}_{\mathrm{X}}$ emissions from previous years to the California Air Resources Board (CARB) in order to determine the historical emissions. Historical $\mathrm{NO}_{\mathrm{X}}$ emissions data from the 1989-1993 compliance years were provided by CARB via a personal data request. Because the $\mathrm{NO}_{\mathrm{X}}$ RTCs were allocated based on the maximum throughput year from 1989 to 1992, inclusive, we use the high value over this time period as a measure of the historical emissions level of the RECLAIM facility (SCAQMD, 1993a).

The variation in the EMSs reflect the difference in abatement costs and abatement potential measured across the different facilities. As some facilities may have installed more effective (and costly) abatement technologies prior to the RECLAIM program, one would expect these facilities to receive more RTCs at the start of the program, since they had already made more aggressive technological improvements. However, because all of the throughput measures and a majority $(65 \%+)$ of the EMSs are facility-specific and therefore not publicly available, we are unable to compare technologies across facilities. Instead, we can only observe the actual RTC allocations and how these allocations differ from the historical emission levels. In this case, it is possible that the determination of the EMSs, particularly those $65 \%+$ that are facility-specific, could be politically motivated.

In our models, we posit that the deviations between historical emissions and the 1994, 2000, and $2003 \mathrm{NO}_{\mathrm{X}}$ RTC allocations reflect the discretionary power of the SCAQMD, and therefore can be used to measure the distributional impacts of the program. In our empirical analysis, we focus not on the allocation itself, but on the deviation between the historical emissions of the facility and the allocation. In this way we are able to capture the distributional rents associated with the differences in allocations, and are able to abstract from the scale-based factors (such as the emissions size of the facility,) which may dominate a simple analysis of allocation.

Given our measure of the distributional impact of the RECLAIM program, we are concerned with the facility-level factors that may have influenced the deviations in $\mathrm{NO}_{\mathrm{X}} \mathrm{RTC}$ allocations to RECLAIM facilities. First, the impact of environmental regulations on employment is a serious concern of SCAQMD regulators. Prior to the start of the RECLAIM program, the claim that a cap and trade system would cause large job losses was made by several RECLAIM facilities, and was successfully defended by the SCAQMD (Superior Court of California, 1993). Because of the attention the SCAQMD regulators dedicated to employment impacts, we are interested in determining whether the employment level of a RECLAIM facility influenced the deviations in the $\mathrm{NO}_{\mathrm{X}}$ RTCs that it was allocated.

Second, the ability of a facility to install technologies to rapidly reduce emissions may have influenced the deviations in the $\mathrm{NO}_{\mathrm{X}}$ RTCs allocated to that facility. Specifically, the size (measured in annual revenues), the profitability, or the debt/equity ratio of the facility or parent company may reflect that the facility is better able to afford the added cost of buying $\mathrm{NO}_{\mathrm{X}}$ credits through the RECLAIM trading market or support the cost of installing abatement technologies. 
Because a large number of facilities in the RECLAIM program are subsidiaries of larger companies, and an even larger number are privately owned, facility-level employment and financial numbers and corporate profitability data are not made publicly available. For this reason we use state-level industry employment and revenue data from the Economic Census to assign employment and revenue values to each facility. Specifically, the 1997 Economic Census provides information on the sales revenue and number of employees for each industry in the North American Industrial Classification System (NAICS) which is the successor to the SIC system. A mapping between the NAICS and the SIC system provided four-digit SIC-specific measures of employment and revenue for each four-digit SIC group in California. The aggregate 1997 Economic Census data was then compared to $1997 \mathrm{CARB}^{\mathrm{NO}} \mathrm{X}$ totals, which were aggregated at the four-digit SIC level for all emitters in California. Together, the 1997 Economic Census data and the 1997 CARB $\mathrm{NO}_{\mathrm{X}}$ emissions data gave us the average 1997 employees per ton of $\mathrm{NO}_{\mathrm{X}}$ in California for each four-digit SIC, as well as the average 1997 revenue per ton of $\mathrm{NO}_{\mathrm{X}}$ in California for each four-digit SIC. The revenue per ton of $\mathrm{NO}_{\mathrm{X}}$ data was normalized using the 1993 price index for California, and was multiplied by the total $\mathrm{NO}_{\mathrm{X}}$ emissions in 1993, recorded by CARB for each facility, to arrive at an estimate of the revenue per facility for 1993. We recognize that our four-digit SIC measures of employment and revenue are secondbest approximations for the facility-level data. As a robustness check, we were able to acquire self-reported employment numbers for a subsample $(\mathrm{N}=107)$ of the RECLAIM facilities, directly from the SCAQMD. We use this data and present the results in Section 4.2.

Finally, we are concerned with the impact that the facilities' emissions of air toxics may have had on the deviations in $\mathrm{NO}_{\mathrm{X}} \mathrm{RTC}$ allocations. Like $\mathrm{NO}_{\mathrm{X}}$, air toxics can react in the atmosphere to produce ozone, and were initially considered for inclusion in the RECLAIM program (USEPA, 2001). In addition, air toxics have been a major concern of environmental lobbies in the SCAQMD - with regards to their spatial concentration and the formation of toxic hotspots (SCAQMD, 2000a; 2000b). In order to measure the toxics emissions of each RECLAIM facility, we collected the 1993 emissions of total organic gases (TOG) from CARB. ${ }^{19}$ The 1993 TOG emission reported by CARB for each RECLAIM facility was then divided by the $1993 \mathrm{NO}_{\mathrm{X}}$ reported for each RECLAIM facility, to arrive at a measure of the tons of toxics per ton of $\mathrm{NO}_{\mathrm{X}}$ emitted in 1993.

\subsection{Trends in RECLAIM Trading Credit Allocations}

Table 1 presents summary information for the facilities included in our analysis. Column (1) shows the major two-digit SICs that were initially included in the RECLAIM program. The heterogeneity of industry types is considerable-ranging from traditionally low-polluting industries such as Engineering firms and Hotels, to higher-polluting industries such as Petroleum Refining and Electric, Gas, and Sanitary services. Column (2) presents the number of facilities in each two-digit SIC category. There were 36 major two-digit SICs that participated in the RECLAIM program in 1994. Of these 36 major two-digit SICs, over $83 \%$ of the facilities fell into one of the 12 largest two-digit SICs, and 13 of the two-digit SICs had two or fewer facilities in them. Column (3) displays the mean two-digit SIC historical $\mathrm{NO}_{\mathrm{X}}$ emissions. The largest historical polluters were the Oil and Gas Extraction facilities (SIC 13), the Petroleum Refineries

\footnotetext{
${ }^{19}$ The total organic gases (TOG) measure provided by the California Air Resources Board includes both the reactive (VOCs) and non-reactive air toxics.
}

(C) Southern Regional Science Association 2013. 
(SIC 29), the Stone, Clay, Glass, and Concrete Products facilities (SIC 32), and the Electric, Gas and Sanitary Services facilities (SIC 49). Together they represented approximately $86 \%$ of the total $\mathrm{NO}_{\mathrm{X}}$ RTCs allocated to the 374 RECLAIM facilities in 1994. In fact, on average, the historical emissions of the largest polluters in the RECLAIM program (Petroleum Refineries) are approximately two orders of magnitude larger than the smallest polluters (Miscellaneous

Table 1: Descriptive Statistics: 2-Digit SIC RECLAIM NOx RTCs and Historical Emissions

\begin{tabular}{|c|c|c|c|c|c|}
\hline \multirow[b]{2}{*}{ 2-digit SIC Category (SIC \#) } & \multirow[b]{2}{*}{$\begin{array}{l}\text { Number of } \\
\text { Facilities }\end{array}$} & \multicolumn{4}{|c|}{ Group Mean Values } \\
\hline & & $\begin{array}{l}\text { Historical Emission } \\
\text { Level (tons NOx) }\end{array}$ & $\begin{array}{c}1994 \\
\text { Allocation }\end{array}$ & $\begin{array}{c}2000 \\
\text { Allocation }\end{array}$ & $\begin{array}{c}2003 \\
\text { Allocation }\end{array}$ \\
\hline Oil and Gas Extraction (13) & 31 & 174.7 & 87.9 & 16.9 & 12.5 \\
\hline Mining (14) & 2 & 21.6 & 9.3 & 0.6 & 0.4 \\
\hline Heavy Construction (16) & 1 & 24.5 & 24.5 & 1.6 & 1.2 \\
\hline Special Trade Contractors (17) & 3 & 12.7 & 15.6 & 2.8 & 2.0 \\
\hline Food Products (20) & 29 & 22.0 & 8.0 & 6.0 & 4.4 \\
\hline Textiles (22) & 19 & 15.3 & 6.8 & 5.2 & 3.8 \\
\hline Apparel (23) & 1 & 7.2 & 3.9 & 2.8 & 2.1 \\
\hline Lumber and Wood Products (24) & 1 & 19.3 & 19.3 & 1.3 & 0.9 \\
\hline Furniture and Fixtures (25) & 1 & 13.0 & 9.3 & 4.5 & 3.2 \\
\hline Paper and Allied Products (26) & 16 & 109.4 & 80.7 & 30.0 & 21.8 \\
\hline Printing (27) & 4 & 32.0 & 30.0 & 19.6 & 14.4 \\
\hline Chemicals and Allied Products (28) & 22 & 36.8 & 25.3 & 19.6 & 14.3 \\
\hline Petroleum Refining (29) & 37 & 517.0 & 324.7 & 129.4 & 93.8 \\
\hline Rubber and Plastics Products (30) & 10 & 8.3 & 4.2 & 2.7 & 2.0 \\
\hline Stone, Clay, Glass, and Concrete Products (32) & 33 & 172.2 & 137.7 & 41.6 & 30.1 \\
\hline Primary Metal Industries (33) & 28 & 27.4 & 32.5 & 16.1 & 11.7 \\
\hline Fabricated Metal Products (34) & 22 & 28.2 & 23.7 & 7.9 & 5.9 \\
\hline Industrial and Commercial Machinery (35) & 6 & 11.7 & 6.1 & 4.4 & 3.2 \\
\hline Electronic Equipment (36) & 6 & 10.2 & 7.5 & 4.7 & 3.5 \\
\hline Transportation Equipment (37) & 20 & 23.0 & 17.1 & 9.8 & 7.2 \\
\hline Instruments (38) & 3 & 10.4 & 9.4 & 3.1 & 2.3 \\
\hline Miscellaneous Manufacturing Industries (39) & 1 & 5.3 & 3.5 & 2.1 & 1.5 \\
\hline Motor Freight Transportation (42) & 1 & 10.8 & 10.8 & 5.7 & 4.1 \\
\hline Transportation By Air (45) & 3 & 70.4 & 69.3 & 10.5 & 7.6 \\
\hline Pipelines, Except Natural Gas (46) & 1 & 9.9 & 3.7 & 3.6 & 2.6 \\
\hline Electric, Gas, and Sanitary Services (49) & 45 & 396.9 & 273.7 & 73.9 & 54.4 \\
\hline Wholesale Trade--Durable Goods (50) & 5 & 27.5 & 11.3 & 3.0 & 2.2 \\
\hline Wholesale Trade--Non-Durable Goods (51) & 4 & 7.8 & 3.4 & 3.2 & 2.3 \\
\hline Food Stores $(54)$ & 4 & 6.8 & 4.6 & 2.9 & 2.1 \\
\hline Depository Institutions (60) & 2 & 24.6 & 22.5 & 11.1 & 8.0 \\
\hline Hotels (70) & 3 & 16.2 & 17.1 & 3.1 & 2.2 \\
\hline Personal Services $(72)$ & 5 & 9.7 & 6.1 & 2.7 & 2.0 \\
\hline Business Services (73) & 1 & 54.3 & 53.6 & 53.4 & 38.7 \\
\hline Miscellaneous Repair Services (76) & 1 & 5.3 & 4.3 & 1.3 & 0.9 \\
\hline Amusement and Recreation Services (79) & 2 & 129.0 & 135.8 & 109.1 & 79.0 \\
\hline Engineering and Management (87) & 1 & 32.4 & 32.4 & 32.4 & 23.4 \\
\hline Total & 374 & & & & \\
\hline Mean & & 146.7 & 98.3 & 33.8 & 24.6 \\
\hline
\end{tabular}

(C) Southern Regional Science Association 2013. 
Manufacturing and Repair SICs). Because the Oil and Gas Extraction, Petroleum Refining, Stone, Clay, Glass, and Concrete Products facilities, and the Electric, Gas and Sanitary Services facilities represent such a large portion of the stationary $\mathrm{NO}_{\mathrm{X}}$ emissions in the SCAQMD, any effective programs to reduce $\mathrm{NO}_{\mathrm{X}}$ emissions must carefully address them. The complete removal of the other 228 facilities in the RECLAIM program would only remove 5,179 tons of $\mathrm{NO}_{\mathrm{X}}$ which represents approximately $19 \%$ of the targeted reduction between 1994 and 2003. Columns (4) through (6) present the mean $\mathrm{NO}_{\mathrm{X}}$ allocations, measured across the 1994, 2000, 2003

allocation years, respectively. There are several points worth noting. First, there is considerable variability in the absolute difference between the historical emission level and the 1994, 2000, and 2003 allocation years when measured across two-digit SIC groups. The absolute difference between the historical emissions level and the 1994 allocation ranges from an increase of 6.8 tons of $\mathrm{NO}_{\mathrm{X}}$ (Amusement and Recreation, SIC 79) to a decrease of 192.3 tons of $\mathrm{NO}_{\mathrm{X}}$ (Petroleum Refining, SIC 29). On average, measured across all industries, the $1994 \mathrm{NO}_{\mathrm{X}} \mathrm{RTC}$ allocation was $-33 \%$ less than the historical emission level.

Second, the industries that were more or less favorably allocated in the 1994 allocation year didn't necessarily receive the same treatment in the 2000 or 2003 allocation years. The Fabricated Metal Products industry (SIC 34), which received a reduction of $16 \%$ between the historical high emissions level and the 1994 allocation year, received a much more severe reduction in the 2000 allocation year - a mean reduction of over $66 \%$ over that timeframe. The Food Products industry (SIC 20) on the other hand, which saw a large decrease in its mean 1994 allocation of $\mathrm{NO}_{\mathrm{X}}$ (over $63 \%$ below the historical emission level,) was compensated in its 2000 allocation of $\mathrm{NO}_{\mathrm{X}}$, with a reduction of only $24 \%$ from the 1994 allocation level.

In summary, the data reveal a large hetereogeneity in allocations and deviations from the historical emission rule, across two-digit SICs. The goal of our empirical analysis will be to explain, systematically, the determinants of these variations.

\subsection{Econometric Model}

In this section we describe the econometric strategy used to measure the effects of industry-level and facility-level characteristics on deviations in $\mathrm{NO}_{\mathrm{X}} \mathrm{RTC}$ allocations. In our empirical models, the dependent variable represents the change in allocation over three distinct periods: between the historical high emission level and the 1994 allocation; between the 1994 and 2000 allocation years; and between the 1994 and 2003 allocation years. If we let $D_{i, t}=$ $R T C_{i, t}-e_{i}$ denote the change in allocation between the historical emission level or the 1994 allocation $\left(e_{i}\right)$, and the $\mathrm{NO}_{\mathrm{X}} \mathrm{RTC}$ allocation in year $t$ (where $\mathrm{t}=1994,2000,2003$,) for facility $i$, then our basic econometric model is Equation (1):

$$
D_{\mathrm{i}, \mathrm{t}}=\beta_{1}+\beta_{2} \text { Size }_{\mathrm{i}}+\beta_{3} \text { Empl }_{\mathrm{i}}+\boldsymbol{\beta}_{\mathbf{4}} \text { Toxics }_{\mathrm{i}}+\eta_{\mathrm{i}, \mathrm{t}}
$$

In the model described by Equation (1), Size represents the annual revenue of the facility, Empl represents the employment per ton of $\mathrm{NO}_{\mathrm{X}}$, and Toxics measures the toxics emissions per ton of $\mathrm{NO}_{\mathrm{X}} . \eta_{\mathrm{i}, \mathrm{t}}$ is the idiosyncratic unobserved error component. We remind the reader that the allocation of $\mathrm{NO}_{\mathrm{X}}$ RTCs was determined prior to the start of the RECLAIM program for each of the 1994 through 2010 allocation years. For this reason, all of the explanatory variables that may have influenced the deviations in allocation are time-invariant across the 1994, 2000, and 2003 years in our analysis.

As noted in the discussion of the descriptive statistics, certain industries may be penalized because of their SIC. Of particular concern to RECLAIM administrators are the Petroleum

(C) Southern Regional Science Association 2013. 
Refineries (SIC 29), and Electric, Gas and Sanitary Services facilities (SIC 49) because they are the largest polluters. ${ }^{20}$ These facilities also tend to be the older facilities in the SCAQMD, with older technologies, and therefore it may be more costly for them to abate. For this reason we include dummy variables for the refineries and electricity, gas and sanitary services producers within the RECLAIM program. ${ }^{21}$

Conversations with air quality management district managers brought to our attention their concern for coastal $\mathrm{NO}_{\mathrm{X}}$ hotspots. By $\mathrm{NO}_{\mathrm{X}}$ hotspots, we refer to areas in which the concentrations of $\mathrm{NO}_{\mathrm{X}}$ are higher than in other areas in the SCAQMD. ${ }^{22}$ Because of the prevailing onshore direction of the winds in the SCAQMD, all facilities in the RECLAIM program are differentiated by the SCAQMD as being a "coastal" or an "inland" facility. ${ }^{23} \mathrm{We}$ therefore include a variable in our analysis that captures the notion of coastal hotspot. For each coastal facility in the RECLAIM program the coastal $\mathrm{NO}_{\mathrm{X}}$ hotspot variable measures the sum of all $1994 \mathrm{NO}_{\mathrm{X}}$ credits allocated to any RECLAIM facilities that are located within a three mile radius of one another. ${ }^{24}$ The addition of SIC dummies and coastal $\mathrm{NO}_{\mathrm{X}}$ hotspots results in Equation (2):

$$
\boldsymbol{D}_{\mathbf{i}, \mathbf{t}}=\boldsymbol{\beta}_{\mathbf{1}}+\boldsymbol{\beta}_{\mathbf{2}} \operatorname{Size}_{\mathbf{i}}+\boldsymbol{\beta}_{\mathbf{3}} \mathbf{E m p l}_{\mathbf{i}}+\boldsymbol{\beta}_{\mathbf{4}} \text { Toxics }_{\mathbf{i}}+\boldsymbol{\alpha} \boldsymbol{C}_{\mathbf{i}}+\sum_{d=0}^{3} N O x_{d}+\boldsymbol{I}_{\mathbf{j}}+\boldsymbol{\eta}_{\mathbf{i}, \mathbf{t}}
$$

where the notation is the same as that which was presented in Equation (1), but adds $N O_{X}$ which represents the sum of all $\mathrm{NO}_{\mathrm{X}}$ emissions within three miles (distance $=d$ ) of each facility, $C_{i}$ as an indicator variable which equals one if the facility is located in the coastal zone, and $\mathbf{I}_{j}$ which is a vector of dummy variables for the Petroleum Refineries and Electric, Gas and Sanitary Services facilities.

As was discussed in the introduction, different publicly elected officials may have different concerns for the facility attributes. As a robustness check, we interact each facility attribute with a dummy variable for each publicly elected representative. There are two exceptions: the SIC of the facility, and the coastal $\mathrm{NO}_{\mathrm{X}}$ hotspot. These regressors are given weights that are uniform across elected officials. The logic behind not interacting the SIC dummy variables with the representative dummy variables results from the fact that these facilities of concern are primarily located in Los Angeles County. ${ }^{25}$ The logic behind not interacting the coastal $\mathrm{NO}_{\mathrm{X}}$ hotspot with the representative dummy variables is that the presence

\footnotetext{
${ }^{20}$ Together SICs 29 and 49 account for 24,333 tons (66\%) of the $1994 \mathrm{NO}_{\mathrm{X}}$ credits that were allocated to RECLAIM facilities.

${ }^{21}$ As a sensitivity analysis, we estimate all of our models with the full cohort of two -digit SIC indicator variables. The inclusion of these regressors does not impact the sign, magnitude or significance of our variables of concern. These sensitivity analyses are available upon request.

${ }^{22}$ Even though the primary concern for $\mathrm{NO}_{\mathrm{X}}$ emissions is their contribution to the formation of ozone, high concentrations of $\mathrm{NO}_{\mathrm{X}}$ can cause lung damage, chronic lung disease, and respiratory infections.

${ }^{23}$ The coastal/inland classification of facilities in the RECLAIM program was defined by the SCAQMD prior to the RECLAIM program, and was originally intended to prevent the creation of $\mathrm{NO}_{\mathrm{X}}$ hotspots. This classification limited the trading opportunities of the RECLAIM facilities: coastal facilities could only acquire $\mathrm{NO}_{\mathrm{X}}$ credits from other coastal facilities, whereas inland facilities could acquire $\mathrm{NO}_{\mathrm{X}}$ credits from either coastal or inland facilities. Of the 374 facilities in the RECLAIM program in 1994,105 $(28 \%)$ were classified as "inland" facilities, and they were allocated 7,937 tons of $\mathrm{NO}_{\mathrm{X}}$ (approximately $22 \%$ of the total 1994 allocation).

${ }^{24}$ The average $\mathrm{NO}_{\mathrm{X}}$ allocated within three miles of a RECLAIM facility in 1994 was 1,184 tons, with a maximum of 10,141 tons, and a minimum of 0 tons.

${ }^{25} 26$ of the 37 Petroleum Refining facilities (SIC 29), and 33 of the 45 Electric, Gas and Sanitary Services facilities (SIC 49) in the RECLAIM program are located in Los Angeles County.
} 
of a coastal $\mathrm{NO}_{X}$ hotspot is a result of the emissions of nearby facilities - which isn't limited by political boundaries. In other words, we have calculated the coastal $\mathrm{NO}_{\mathrm{X}}$ hotspots for all RECLAIM $\mathrm{NO}_{\mathrm{X}}$ emissions within three miles, regardless of representative. It is unlikely that an elected official will penalize a facility that contributes to a $\mathrm{NO}_{\mathrm{X}}$ hotspot only if it falls within their purview. In this case, it is the size of the hotspot as opposed to the location of the hotspot that matters.

The coefficients and standard errors from Equation (2) could have been estimated using ordinary least squares. However, preliminary tests indicate that the error terms exhibit positive spatial autocorrelation. ${ }^{26}$ With spatial autocorrelation, the standard errors that we recover from ordinary least square methods are inaccurate.

The literature uses two general approaches to correct for spatial autocorrelation. The first imposes a parametric structure on the spatial autocorrelation by using a weighting matrix to specify the correlation of the error terms. If the error structure is incorrectly specified, then the variance-covariance matrix is inconsistent. The second relies on a non-parametric approach that avoids the need to specify a weighting matrix, but rather uses weighted averages of the spatial autocovariance terms to correct the standard errors of the coefficients for possible spatial serial dependence (Conley, 1999). This nonparametric approach uses a generalized method of moments estimator that is just-identified, to arrive at coefficient results that are identical to the ordinary least squares point estimates, but provides consistent standard error estimates. We utilize the latter, and present the robust spatially corrected standard errors. ${ }^{27,28}$

\section{RESULTS}

We begin our analysis of the empirical results by looking at the estimates of Equation (2) presented in Tables 2 and 4. We then present marginal effects for subsamples of the dataset, by facility size, presented in Table 5.

\subsection{What determines the deviations in $\mathrm{NO}_{\mathrm{X}}$ credit allocations?}

The effects of facility characteristics on the deviations in $\mathrm{NO}_{\mathrm{X}}$ credit allocations appear in Table 2. In this case, the least squares results and spatially corrected errors are consistent with our predictions - they indicate that the employment ratio, the toxics ratio, the coastal $\mathrm{NO}_{\mathrm{X}}$ hotspots, and the facility size all have statistically significant impacts on the deviations in $\mathrm{NO}_{\mathrm{X}}$ credit allocations in 1994.

\footnotetext{
${ }^{26}$ The Moran's I (0.199) and Geary's C (0.930) statistics estimate a weighted correlation coefficient that can be used to detect for spatial patterns in the data. Moran's I is the most commonly used specification test for spatial autocorrelation; Anselin (1988), and Cliff and Ord (1973) present the derivation of the Moran's I statistic, and detailed explanations of the conditions that can lead to spatial autocorrelation of the error term.

${ }^{27}$ The Conley (1999) approach allows the researcher to specify a cutoff distance beyond which the spatial correlation is equal to zero. This approach is robust to any misspecification of the spatial dependence between the individual observations. We use the latitude and longitude of the individual facilities to define the cutoff distance, which is set at 0.1 degrees (or approximately 7 miles). In this case the spatial correlation between facilities declines linearly as the distance between the facilities increases, and is zero beyond seven miles.

${ }^{28}$ daMatta et al. (2005) use the Conley (1999) correction for spatial autocorrelation to correct for interactions between cities and spillover of technologies in the determination of city growth in Brazil; Rappaport and Sachs (2001) use the Conley (1999) correction for spatial autocorrelation to correct for omitted geographic variables in their analysis of the impact of the proximity of cities to the coast on productivity and quality of life.
} 


\begin{tabular}{lccc} 
Table 2: Least Squares Results of RECLAIM Trading Credit Allocation Change & \\
\hline \hline Model: & 1 & 2 & 3 \\
Dep Var: & $1994-$ Historical & $2000-1994$ & $2003-1994$ \\
\hline Size & -0.296 & -0.372 & -0.422 \\
& {$[0.097]^{* *}$} & {$[0.086]^{* *}$} & {$[0.093]^{* *}$} \\
Employment & 0.473 & 0.598 & 0.679 \\
& {$[0.174]^{* *}$} & {$[0.174]^{* *}$} & {$[0.199]^{* *}$} \\
Toxics & -0.758 & 0.168 & 0.071 \\
& {$[0.378]^{*}$} & {$[0.197]$} & {$[0.188]$} \\
NOx * Coast & -0.011 & -0.008 & -0.010 \\
& {$[0.006]^{+}$} & {$[0.005]$} & {$[0.006]^{+}$} \\
Refinery (SIC 29) & -41.798 & -21.596 & -31.836 \\
& {$[21.537]^{+}$} & {$[22.414]$} & {$[25.748]$} \\
Electricity (SIC 49$)$ & -26.29 & -83.893 & -86.545 \\
& {$[27.251]$} & {$[25.909]^{* *}$} & {$[27.386]^{* *}$} \\
Constant & 9.818 & -2.986 & -3.060 \\
& {$[4.748]^{*}$} & {$[8.236]$} & {$[9.422]$} \\
\hline Observations & 374 & 374 & 374 \\
Adjusted R-squared & 0.51 & 0.59 & 0.60 \\
\hline Notes: Huber-Eicker-White robust estimates of the standard errors with correction for spatial correlation & \\
(Bartlett Window of 0.1 Degrees) are provided in brackets & & & \\
Significance: ${ }^{+} \mathrm{P}<.10 ;{ }^{*} \mathrm{P}<.05 ; * * \mathrm{P}<.01$ & & & \\
\hline \hline & & & \\
\hline
\end{tabular}

Specifically, the size of the facility has a negative effect on the deviation in $\mathrm{NO}_{\mathrm{X}}$ credit allocations. A single standard-deviation increase in the revenue of a facility $(\$ 420 \mathrm{M})$ translates into a 1994 allocation of $\mathrm{NO}_{\mathrm{X}}$ that is 124 tons less than the average historical emission level. ${ }^{29}$ The employment to $\mathrm{NO}_{\mathrm{X}}$ ratio has a positive effect on the deviation in $\mathrm{NO}_{\mathrm{X}}$ credit allocations. A single standard-deviation increase in the employees per ton of $\mathrm{NO}_{\mathrm{X}}$ (103 employees) translates into a 1994 allocation of $\mathrm{NO}_{\mathrm{X}}$ that is 49 tons above the historical emission level. The toxics ratio has a negative effect on the deviation in $\mathrm{NO}_{\mathrm{X}}$ credit allocation. A single standard-deviation increase in the toxics per ton of $\mathrm{NO}_{\mathrm{X}}$ (31 tons) translates into a 1994 allocation of $\mathrm{NO}_{\mathrm{X}}$ that is 23 tons below the historical emission level. And finally, facilities that are located in coastal $\mathrm{NO}_{\mathrm{X}}$ hotspots are underallocated relative to facilities that don't fall in coastal $\mathrm{NO}_{\mathrm{X}}$ hotspots. A single standard-deviation increase in a coastal $\mathrm{NO}_{\mathrm{X}}$ hotspot (2243 tons of $\mathrm{NO}_{\mathrm{X}}$ ) translates into an underallocation of 25 tons of $\mathrm{NO}_{\mathrm{X}}$, relative to the historical emission level. Of the two industries of concern, Electric, Gas and Sanitary Services Facilities, and Petroleum Refineries, only the Petroleum Refineries have a significant impact on the deviation in initial allocation from historical emissions - reducing the initial allocation by approximately 42 tons below the historical emission level.

\footnotetext{
${ }^{29}$ It is possible that the size of the facility may, at least in part, be picking up the effects of the facility's initial $\mathrm{NO}_{\mathrm{X}}$ emissions. Those facilities with higher $\mathrm{NO}_{\mathrm{X}}$ emissions may have higher revenues, since NOx emissions are used to impute revenue. Therefore those facilities with high $\mathrm{NO}_{\mathrm{X}}$ emissions might be asked to reduce their emissions more aggressively. While we attribute this reduction to higher revenues, it may simply be due to unusually large $\mathrm{NO}_{\mathrm{X}}$ emissions. Unfortunately, due to data limitations we are unable to directly address this possibility, however we do account for the impact that the inclusion of the size of the facility may have on our other independent variables in our robustness checks in Section 4.2.
} 


\subsection{Robustness Checks}

Industry-level measures of employment and revenue are second-best approximations of the actual facility-level characteristics. Unfortunately, publicly-available facility-level employment and revenue data isn't available for the facilities in our analysis. However, we were able to collect a smaller sample $(\mathrm{N}=107)$ of employment totals, provide by the SCAQMD through a records request, which has been extracted from a (optional) self-reported survey that was conducted by the SCAQMD at the beginning of the RECLAIM program. This smaller sample of employment statistics, although not a perfect match to our employment data, has a positive correlation (Pearson correlation coefficient $=0.61$ ).

As a robustness check to our base model (1) in Table 2, we present three sets of models in Table 3. Model (1) presents the baseline model (1) from Table 2. Model (2) drops the two variables of concern that were constructed by using four-digit SIC industry employment and revenue measures. Model (3) includes the new employment measure, constructed in the same way as the employment measure in model (1), but with the facility-level employment totals.

Two points are worth noting. First, when we drop the variables of concern, the coefficient estimates presented in model (2) are consistent, in sign and significance, with those presented in model (1). The magnitudes of the observed coefficients are generally larger, likely picking up some of the positive correlation between employment, revenue and the pollutants that we are analyzing. Second, using a smaller subsample of the data with actual facility-level employment

\begin{tabular}{|c|c|c|c|}
\hline Dep Var: 1994-Historical & & & \\
\hline Model: & 1 & 2 & 3 \\
\hline Dep Var: & 1994-Historical & 1994-Historical & 1994-Historical \\
\hline Size & $\begin{array}{c}-0.296 \\
{[0.097]^{* *}}\end{array}$ & & \\
\hline Old Employment & $\begin{array}{c}0.473 \\
{[0.174]^{* *}}\end{array}$ & & \\
\hline New Employment & & & $\begin{array}{c}0.148 \\
{[0.044]^{* *}}\end{array}$ \\
\hline Toxics & $\begin{array}{c}-0.758 \\
{[0.378]^{*}}\end{array}$ & $\begin{array}{c}-1.179 \\
{[0.692]^{+}}\end{array}$ & $\begin{array}{l}-1.595 \\
{[1.031]}\end{array}$ \\
\hline NOx * Coast & $\begin{array}{c}-0.011 \\
{[0.006]^{+}}\end{array}$ & $\begin{array}{c}-0.022 \\
{[0.007]^{* *}}\end{array}$ & $\begin{array}{c}-0.027 \\
{[0.011]^{*}}\end{array}$ \\
\hline Refinery (SIC 29) & $\begin{array}{c}-41.798 \\
{[21.537]^{+}}\end{array}$ & $\begin{array}{c}-125.891 \\
{[59.521]^{*}}\end{array}$ & $\begin{array}{c}-235.708 \\
{[91.359]^{*}}\end{array}$ \\
\hline Electricity (SIC 49) & $\begin{array}{c}-26.29 \\
{[27.251]}\end{array}$ & $\begin{array}{c}-81.704 \\
{[31.581]^{*}}\end{array}$ & $\begin{array}{c}-75.075 \\
{[95.991]}\end{array}$ \\
\hline Constant & $\begin{array}{c}9.818 \\
{[4.748]^{*}}\end{array}$ & $\begin{array}{c}8.973 \\
{[6.658]}\end{array}$ & $\begin{array}{c}4.052 \\
{[7.348]}\end{array}$ \\
\hline Observations & 374 & 374 & 107 \\
\hline Adjusted R-squared & 0.51 & 0.20 & 0.37 \\
\hline \multicolumn{4}{|c|}{$\begin{array}{l}\text { Notes: Huber-Eicker-White robust estimates of the standard errors with correction for spatial correlation } \\
\text { (Bartlett Window of } 0.1 \text { Degrees) are provided in brackets } \\
\text { Significance: }{ }^{+} \mathrm{P}<.10 ; * \mathrm{P}<.05 ;{ }^{* *} \mathrm{P}<.01\end{array}$} \\
\hline
\end{tabular}

(C) Southern Regional Science Association 2013. 
measures results in coefficient estimates that are similar in sign (although, expectedly, not in magnitude) with those in model (1). In this model we lose the significance of the toxics ratio coefficient, and the magnitudes of the SIC dummy variables change (which may reflect the changing industrial composition of the subsample) but the general trends that we observe in our base model (1) persist.

\subsection{Do the factors that influence the deviations in $\mathrm{NO}_{\mathrm{X}}$ credit allocations vary over time?}

When looking at how the determinants of $\mathrm{NO}_{\mathrm{X}}$ credit allocations vary over time, we note two important and somewhat intriguing results from Table 3. First, it appears that regulators are using the RECLAIM program to regulate toxics in the short run (based on the deviation between the historical emissions level and the 1994 RTC allocation level,) when fewer trades take place. The coefficient on the deviation between historical emissions and the 1994 allocation level is significant at the 5\% level, but the coefficients on the deviations between the 1994 and 2000 allocations, and between the 1994 and 2003 allocations are not significant. There are several plausible explanations for this: First, the regulators may have been concerned about the direct impact of toxics emissions, and chose to reduce the 1994 RTC allocation to those facilities for which the toxics to $\mathrm{NO}_{\mathrm{X}}$ ratio is high. Second, in the same way that $\mathrm{NO}_{\mathrm{X}}$ reacts in the atmosphere to form ozone, certain toxics can contribute to the overall ozone problem. If the primary mission of the regulators is to reduce the emissions of ozone-causing air pollutants, then the facilities with large toxics to $\mathrm{NO}_{\mathrm{X}}$ ratios may be underallocated. Third, the toxics that are emitted by the RECLAIM facilities are exceptionally diverse, and the regulations that have been put in place to control toxics emissions are not as stringent as the $\mathrm{NO}_{\mathrm{X}}$ regulations. ${ }^{30}$ This makes it much harder to control the emissions of toxics directly, and all the more convenient to use the RECLAIM program to do so.

Consistent with economic theory, the toxics to NOx ratio is only significant in explaining the deviations surrounding the $1994 \mathrm{NO}_{\mathrm{X}}$ credit allocations. In the absence of trade, a marketbased credit system degrades to a simple command and control system and thus forces facilities to reduce their toxic emissions. Therefore, in the absence of trade, the initial $\mathrm{NO}_{\mathrm{X}}$ allocation allows the regulators to directly regulate toxics emissions. Over time, with increases in trade and the installation of abatement technologies, the regulators lose some of their ability to control toxics emissions and the resulting toxic hotspots. These expectations are reflected in our results. We find that the coefficients on the toxics to $\mathrm{NO}_{\mathrm{X}}$ variables are not significant in models (2) and (3) of Table 3 which look at $\mathrm{NO}_{\mathrm{X}}$ RTC allocations in the later time periods.

The second intriguing result is that in these models, the Electric, Gas and Sanitary Services dummy variable isn't significant in explaining the deviations between historical emissions levels and the $1994 \mathrm{NO}_{\mathrm{X}}$ credit allocations. However, the Electric, Gas and Sanitary Services dummy variable is negative and becomes highly significant as we look at the later periods. These results are consistent with the findings of Joskow and Schmalensee (1998) who analyze credit allocations in the U.S. acid rain program. Joskow and Schmalensee (1998) show that in the early years of the program, more sulfur dioxide emission credits were allocated to the more highly emitting electric utilities, and that these same electric utilities were allocated fewer

\footnotetext{
${ }^{30}$ Recall that in 1991, there were 181 separate air toxics emitted across 58,000 different emission sources within the SCAQMD. As of March 2000, the SCAQMD had eight local regulations in place ("airborne toxics control measures" (ATCMs)) to control for the stationary sources of air toxics within the SCAQMD. Most of these ATCMs rely on estimates of the cancer risk from exposure to air toxics as a justification for enforcement and regulation, which further complicates their regulatory efforts.
} 
allowances in the later years of the program. The abatement technologies necessary to reduce emissions within the electric utility sector, including the installation of scrubbers and new burner units, are extremely costly. ${ }^{31}$ The short run leniency and long run strictness in $\mathrm{NO}_{\mathrm{X}}$ credit allocations can be viewed as a compensation or subsidization of these high costs. Our results suggest a similar pattern.

\begin{tabular}{|c|c|c|c|}
\hline Model: & 1 & 2 & 3 \\
\hline Dep Var: & 1994-Historical & 2000-1994 & 2003-1994 \\
\hline LAC Size & $\begin{array}{c}-0.284 \\
{[0.109]^{* *}}\end{array}$ & $\begin{array}{c}-0.356 \\
{[0.092]^{* *}}\end{array}$ & $\begin{array}{c}-0.405 \\
{[0.106]^{* *}}\end{array}$ \\
\hline LAC Employment & $\begin{array}{c}0.459 \\
{[0.248]^{+}}\end{array}$ & $\begin{array}{c}0.576 \\
{[0.269]^{*}}\end{array}$ & $\begin{array}{c}0.656 \\
{[0.308]^{*}}\end{array}$ \\
\hline LAC Toxics & $\begin{array}{c}-0.973 \\
{[0.512]^{+}}\end{array}$ & $\begin{array}{c}0.197 \\
{[0.254]}\end{array}$ & $\begin{array}{c}0.079 \\
{[0.252]}\end{array}$ \\
\hline OC Size & $\begin{array}{c}-0.518 \\
{[0.056]^{* *}}\end{array}$ & $\begin{array}{c}-0.436 \\
{[0.046]^{* *}}\end{array}$ & $\begin{array}{c}-0.488 \\
{[0.052]^{* *}}\end{array}$ \\
\hline OC Employment & $\begin{array}{c}0.802 \\
{[0.067]^{* *}}\end{array}$ & $\begin{array}{c}0.686 \\
{[0.049]^{* *}}\end{array}$ & $\begin{array}{c}0.767 \\
{[0.055]^{* *}}\end{array}$ \\
\hline OC Toxics & $\begin{array}{c}-0.188 \\
{[0.484]}\end{array}$ & $\begin{array}{c}-0.102 \\
{[0.064]}\end{array}$ & $\begin{array}{c}-0.112 \\
{[0.072]}\end{array}$ \\
\hline SBC Size & $\begin{array}{c}-0.109 \\
{[0.076]}\end{array}$ & $\begin{array}{c}-0.618 \\
{[0.275]^{*}}\end{array}$ & $\begin{array}{c}-0.685 \\
{[0.300]^{*}}\end{array}$ \\
\hline SBC Employment & $\begin{array}{c}-0.146 \\
{[0.252]}\end{array}$ & $\begin{array}{c}0.276 \\
{[0.839]}\end{array}$ & $\begin{array}{c}1.401 \\
{[0.914]}\end{array}$ \\
\hline SBC Toxics & $\begin{array}{c}0.506 \\
{[0.390]}\end{array}$ & $\begin{array}{c}0.274 \\
{[0.841]}\end{array}$ & $\begin{array}{c}0.066 \\
{[0.885]}\end{array}$ \\
\hline RC Size & $\begin{array}{c}-0.137 \\
{[0.106]}\end{array}$ & $\begin{array}{c}-0.262 \\
{[0.111]^{*}}\end{array}$ & $\begin{array}{c}-0.286 \\
{[0.116]^{*}}\end{array}$ \\
\hline RC Employment & $\begin{array}{c}-0.451 \\
{[0.172]^{* *}}\end{array}$ & $\begin{array}{c}0.331 \\
{[0.247]}\end{array}$ & $\begin{array}{c}0.353 \\
{[0.256]}\end{array}$ \\
\hline RC Toxics & $\begin{array}{c}0.688 \\
{[0.348]^{*}}\end{array}$ & $\begin{array}{c}-0.246 \\
{[0.282]}\end{array}$ & $\begin{array}{c}-0.608 \\
{[0.316]^{+}}\end{array}$ \\
\hline NOx $*$ Coast & $\begin{array}{c}-0.009 \\
{[0.006]^{+}}\end{array}$ & $\begin{array}{c}-0.009 \\
{[0.006]^{+}}\end{array}$ & $\begin{array}{c}-0.010 \\
{[0.006]^{+}}\end{array}$ \\
\hline Refinery (SIC 29) & $\begin{array}{l}-32.628 \\
{[25.051]}\end{array}$ & $\begin{array}{c}-24.576 \\
{[20.734]}\end{array}$ & $\begin{array}{l}-34.850 \\
{[24.012]}\end{array}$ \\
\hline Electricity (SIC 49) & $\begin{array}{c}-27.333 \\
{[26.802]}\end{array}$ & $\begin{array}{c}-86.271 \\
{[26.050]^{* *}}\end{array}$ & $\begin{array}{c}-88.838 \\
{[27.471]^{* *}}\end{array}$ \\
\hline Constant & $\begin{array}{c}7.121 \\
{[4.750]}\end{array}$ & $\begin{array}{c}-0.161 \\
{[7.353]}\end{array}$ & $\begin{array}{c}-1.61 \\
{[8.376]}\end{array}$ \\
\hline $\begin{array}{l}\text { Observations } \\
\text { Adjusted R-squared }\end{array}$ & $\begin{array}{l}374 \\
0.53\end{array}$ & $\begin{array}{l}374 \\
0.60\end{array}$ & $\begin{array}{l}374 \\
0.61\end{array}$ \\
\hline
\end{tabular}

${ }^{31}$ In 2001 the upgrade (installation of new burners and abatement technologies) of a 450 megawatt electricity production facility in Orange County was estimated to have a capital cost of $\$ 130$ million, with a total construction payroll of $\$ 45$ million (California Energy Commission, 2001). 


\subsection{Do the different representatives share similar concerns?}

Table 4 presents the impacts of political representation on the deviations in allocation, and three important results stand out. First, for the deviation between 1994 and the historical emission level, the facility size variable is only significant in Orange County and Los Angeles County. ${ }^{32}$ The coefficient on the size of the facility is -0.284 in Los Angeles County, and -0.518 in Orange County. As we expand the timeframe of the analysis and look at the deviations between 1994 and 2000, and between 1994 and 2003, the facility size variable becomes significant for both San Bernardino County and Riverside County. Both of the coefficients maintain the same (negative) sign and relative magnitude as those in Los Angeles County and Orange County, both of which remain significant.

Second, the coefficient on the employment ratio of the facility is positive and significant for Los Angeles County and Orange County: the coefficient is 0.431 in Los Angeles County, and 0.756 in Orange County. ${ }^{33}$ However, the coefficient on the employment ratio for the deviation between the 1994 allocation and the historical emission level is negative and significant for Riverside County. We are unable to reconcile the sign on the coefficient for Riverside County, but note that sign changes for models (2) and (3), and that the marginal effect remains very small (-2.5 tons).

Third, the impact of toxics on the deviation between 1994 and the historical emission level is only significant for Los Angeles County and Riverside County. However, the coefficient for Riverside County has the perverse (positive) sign. The result for Los Angeles County is consistent with the SCAQMD's Multiple Air Toxics Exposure Study II (2000a) report that found that the areas with the highest toxics concentrations in the SCAQMD were in Los Angeles County. Again, we are unable to reconcile the sign on the coefficient for Riverside County, but note that the marginal effect remains very small (1.5 tons), and changes sign (and becomes significant) as we look at the future allocation periods in models (2) and (3).

\subsection{What is the impact of facility size on the deviations in the allocation of $\mathrm{NO}_{\mathrm{X}}$ credits?}

Facilities were grouped into three sizes, and the standard deviation for each group was calculated: small facilities with less than $\$ 10 \mathrm{M}$ in annual revenue, medium facilities with $\$ 10 \mathrm{M}$ to $\$ 50 \mathrm{M}$ in annual revenue, and large facilities with over $\$ 50 \mathrm{M}$ in revenue. Table 5 presents these calculations, using the county representative interactions from Table 4.

The marginal effects presented in Table 5 show that a single standard-deviation increase in the revenue of a large facility in Los Angeles County (\$641M) translates into a 1994 allocation of $\mathrm{NO}_{\mathrm{X}}$ that is 182 tons less than the historical average emission level. Likewise, a one standard deviation increase in the revenue of a large facility in Orange County (\$267M) translates into a 1994 allocation of $\mathrm{NO}_{\mathrm{X}}$ that is 228 tons less than the historical average emission level. The magnitudes of the effects are dominated by the larger (revenue $>\$ 50 \mathrm{M}$ ) facilities in both representative areas. These results are consistent with the notion that larger facilities are

\footnotetext{
${ }^{32}$ We remind the reader that the vast majority of the RECLAIM facilities are in these two counties: 250 (67\%) are located in Los Angeles County, and $58(16 \%)$ are in Orange County.

${ }^{33}$ Of interest is whether Los Angeles County and Orange County representatives place the same concerns on the facility size and employment ratio. T-tests suggest that the differences in coefficient outcomes are statistically different from zero, implying that different representatives do in fact put different weights on the size and employment ratio characteristics of firms.
} 
more likely to be able to support the large fixed cost of the technologies installed to reduce emissions.

Table 5 also presents the impact of employees per ton of $\mathrm{NO}_{\mathrm{X}}$ on deviations in the allocation of NOX credits. Again, the magnitudes of the effects are dominated by the larger facilities in both the Los Angeles County and Orange County areas - the marginal effect for a large facility in Los Angeles County is 62 tons (in comparison to 5 tons for medium facility, and

Table 5: Effects of Least Squares RECLAIM Trading Credit Results of Allocation Change with County Representative Interactions

\begin{tabular}{|c|c|c|c|c|c|c|c|c|c|}
\hline \multirow{2}{*}{$\begin{array}{l}\text { Marginal Effects Period: } \\
\text { Size: }\end{array}$} & \multicolumn{3}{|c|}{ (1994 - Historical) } & \multicolumn{3}{|c|}{ (2000-1994) } & \multicolumn{3}{|c|}{ (2003-1994) } \\
\hline & small & medium & large & small & medium & large & small & medium & large \\
\hline LAC Size & -1 & -4 & -182 & -1 & -5 & -228 & -1 & -6 & -260 \\
\hline LAC Employment & 2 & 5 & 62 & 3 & 6 & 78 & 3 & 7 & 89 \\
\hline LAC Toxics & -21 & -33 & -26 & 4 & 7 & 5 & 2 & 3 & 2 \\
\hline OC Size & -1 & -5 & -138 & -1 & -5 & -116 & -1 & -5 & -130 \\
\hline OC Employment & 5 & 8 & 96 & 5 & 7 & 82 & 5 & 7 & 92 \\
\hline OC Toxics & -4 & 0 & -1 & -2 & 0 & -1 & -3 & 0 & -1 \\
\hline SBC Size & 0 & -1 & -15 & -1 & -4 & -84 & -1 & -5 & -94 \\
\hline SBC Employment & 0 & -1 & -1 & 0 & 2 & 3 & 1 & 8 & 14 \\
\hline SBC Toxics & 2 & 0 & 2 & 1 & 0 & 1 & 0 & 0 & 0 \\
\hline RC Size & 0 & -1 & -5 & 0 & -2 & -9 & 0 & -2 & -10 \\
\hline RC Employment & 0 & -3 & -2 & 0 & 2 & 1 & 0 & 3 & 1 \\
\hline RC Toxics & 1 & 2 & 0 & 0 & -1 & 0 & 0 & -2 & 0 \\
\hline NOx $*$ Coast & -18 & -18 & -23 & -18 & -18 & -23 & -20 & -20 & -26 \\
\hline $\mathrm{N}:$ & 128 & 126 & 120 & 128 & 126 & 120 & 128 & 126 & 120 \\
\hline
\end{tabular}

2 tons for a small facility) and the marginal effect for a large facility in Orange County is 96 tons (in comparison to 8 tons for a medium facility, and 5 tons for a small facility).

Increasing the toxics per ton of $\mathrm{NO}_{\mathrm{X}}$ of a large facility in Los Angeles County by one standard deviation (26.4 tons toxics/ton $\mathrm{NO}_{\mathrm{X}}$ ) results in a 1994 allocation of $\mathrm{NO}_{\mathrm{X}}$ that is 26 tons below the historical emission level. Of note here is the impact that the size of the facility has on the deviation in the $\mathrm{NO}_{\mathrm{X}}$ credit allocation: the effect of the large facilities is smaller than the effect of the medium facilities. Although the marginal effect is smaller for small firms (-21 tons $\left.\mathrm{NO}_{\mathrm{X}}\right)$, it is largest for medium-sized firms ( -33 tons $\left.\mathrm{NO}_{\mathrm{X}}\right)$. The size of the facility does not 
appear to be indicative of the toxic intensity of its production process. ${ }^{34}$ If a regulator is concerned with reducing toxics, then their greatest concern should be the toxics to $\mathrm{NO}_{\mathrm{X}}$ ratio, regardless of facility size.

As was noted in the previous section, the marginal effects for the coefficients that had perverse signs are relatively small, when compared to those with the expected signs. Specifically, the marginal effects for the employees per ton of $\mathrm{NO}_{\mathrm{X}}\left(-2\right.$ tons $\mathrm{NO}_{\mathrm{X}}$ for the largest facilities) and the toxics per ton of $\mathrm{NO}_{\mathrm{X}}\left(\sim 0\right.$ tons $\mathrm{NO}_{\mathrm{X}}$ for the largest facilities) in Riverside County are both a very small fraction of those presented for Los Angeles County and Orange County.

\subsection{What are the distributional impacts of the RECLAIM program?}

The deviations from the historical emissions rule translate into rent-based costs or benefits for the individual facilities: those that were allocated more credits than they needed were able to trade them on the open market for revenue, or were able to avoid the need to install costly abatement technologies in future periods; those that were allocated fewer $\mathrm{NO}_{\mathrm{X}}$ credits than they needed were forced to use the market to acquire credits, or to install abatement technologies to achieve compliance. These deviations between the historical emission levels and the 1994 allocation allow us to analyze the cost implications of the program. There are four potential outcomes given that a facility is underallocated in terms of its $\mathrm{NO}_{\mathrm{X}}$ credits relative to its historical emissions level: First, the facility could install abatement equipment to meet their underallocation; second, the facility could use the $\mathrm{NO}_{\mathrm{X}}$ trading market to acquire additional permits; third, assuming that the $\mathrm{NO}_{\mathrm{X}}$ trading market isn't functioning properly, they could continue with business-as-usual, and incur the backstop price per ton of $\mathrm{NO}_{\mathrm{X}}$; and fourth, they could alter their production processes, thus reducing their emissions to the allocated level, or, as a worst-case outcome, they could halt production in the SCAQMD area altogether.

Assessment of the costs associated with the installation of abatement technologies is impossible to determine without insight into the current technologies that the facility has installed, which is proprietary. However, we are able to provide estimates of the last three potential outcomes. ${ }^{35}$ The average $\mathrm{NO}_{\mathrm{X}}$ trading price in 1994 was $\$ 678$ per ton. The total underallocation of 18,086 tons between the historical high emission level and the 1994 allocation level would result in a net rent transfer of $\$ 12.26 \mathrm{M}$. The backstop price of $\$ 15 \mathrm{k}$ per ton, which was achieved during the 2000/2001 trading year, would result in a rent transfer of $\$ 271 \mathrm{M}$ over the same period. If the entire production processes in RECLAIM facilities were scaled back by the percentage of the underallocation, the total loss to the SCAQMD economy would be approximately $\$ 11.1 \mathrm{~B}$, measured as a fractional sum of the total industry-specific revenue per ton of $\mathrm{NO}_{\mathrm{X}}$. The revenue for all RECLAIM facilities in the SCAQMD is measured at over \$57B (all measured in \$1993).

In addition to the distribution of rents in the SCAQMD, the results of our empirical models presented in Table 4 indicate that political representation and the preferences of publicly elected officials have significant effects on the $\mathrm{NO}_{\mathrm{X}}$ allocations that facilities were granted. In

\footnotetext{
${ }^{34}$ The Pearson correlation coefficient between toxics per ton of $\mathrm{NO}_{\mathrm{X}}$ and the revenue of the facility is weakly positive: 0.147.

${ }^{35}$ The SCAQMD has calculated the average RECLAIM Trading Credit price for the three years that we analyze: A total of 2,210 tons of $\mathrm{NO}_{\mathrm{X}}$ RECLAIM Trading Credit were traded in 1994 for a total of $\$ 1.5 \mathrm{M}$, or roughly $\$ 678 /$ ton; 8,316 tons of $\mathrm{NO}_{\mathrm{X}}$ RECLAIM Trading Credits were traded in 2000 for a total of $\$ 177.2 \mathrm{M}$, or $\$ 21,308 /$ ton; a recent publication by the SCAQMD places a value of $\$ 3,759 /$ ton for $2003 \mathrm{NO}_{\mathrm{X}}$ Trading Credits.
}

(C) Southern Regional Science Association 2013. 
Table 6: Mean Allocations (tons) of RECLAIM Trading Credits by SIC and Location

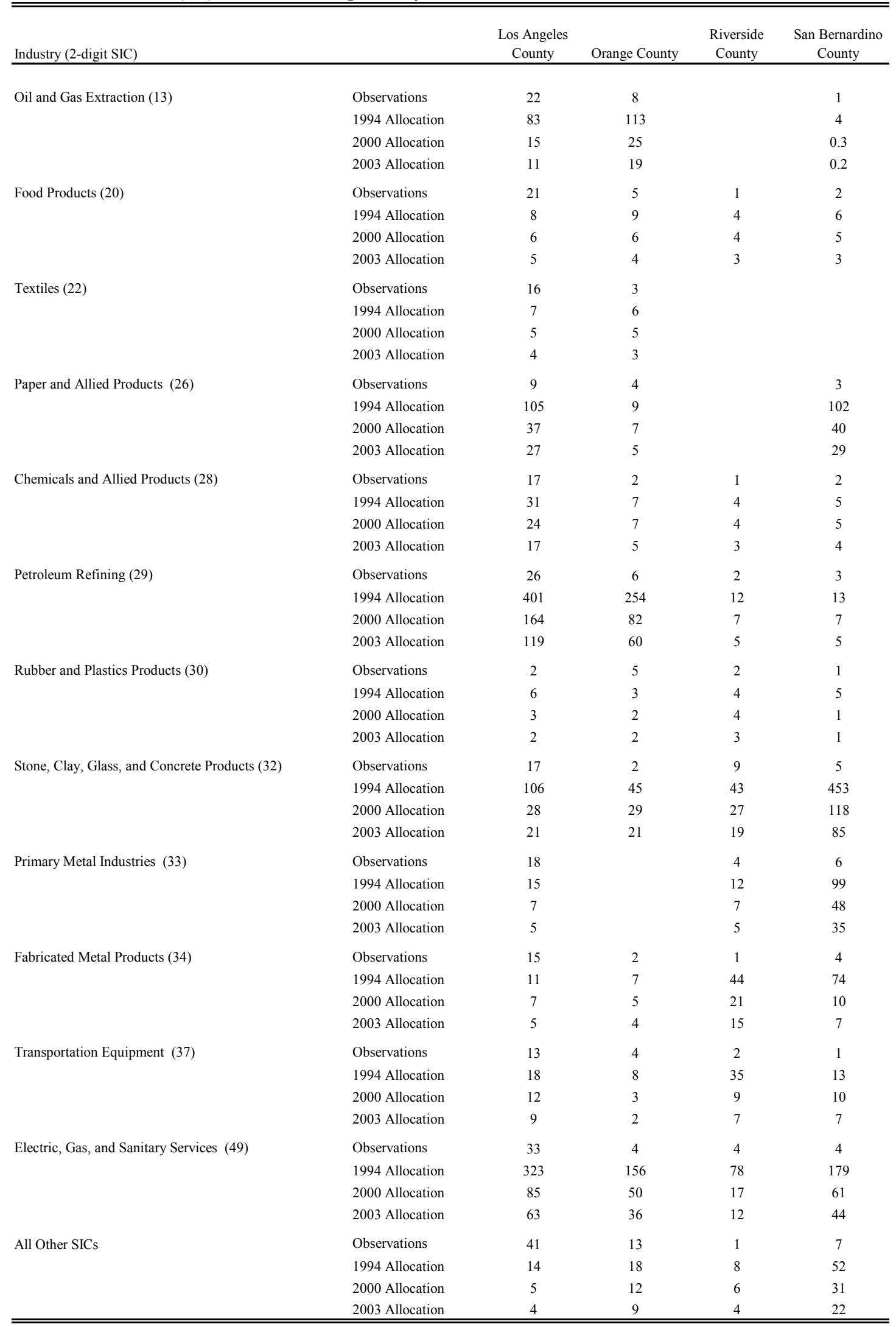


order to demonstrate the potential costs or benefits associated with the location of a facility, we use the allocations that facilities were given in 1994, 2000, and 2003, and the average trading price of RECLAIM NO $\mathrm{N}_{\mathrm{X}}$ credits during those years. This information allows us to determine the rents that were provided to facilities through the allocation mechanism. Comparing allocations, within industries, across representatives, allows us to determine the cost or benefit associated with a particular facility, and with a particular representative.

Tables 7 and 8 use the average industry allocation information presented in Table 6 to determine the rent transfer associated with moving an "average" facility from one representative area to another. We've chosen two industries for this cost of distribution analysis: the Electric Gas and Sanitary Services (SIC 49) and Petroleum Refining (SIC 29). The inclusion of these two industry segments is self-explanatory - they were included as industry-fixed effects in our regression models, have been discussed in detail by the SCAQMD as being key industries for the program, and the facilities within each category are relatively homogeneous.

In general, these tables verify that there are location-specific rents associated with the program, and that the rents are not uniform. In Table 7, a movement of an average Electric, Gas and Sanitary Services (SIC 49) facility from Los Angeles County to Orange County translates into a reduction in 167 tons of $\mathrm{NO}_{\mathrm{X}}$ in 1994, which is roughly equal to $\$ 113 \mathrm{k}$. This same facility, if moved to Riverside County, would receive 246 fewer tons of $\mathrm{NO}_{\mathrm{X}}$, or $\$ 167 \mathrm{k}$. Similar results are found for the Petroleum Refining Facilities (SIC 29) in Table 8, where we see that the movement of an average refinery from Los Angeles County to Orange County results in a rent loss of $\$ 99 \mathrm{k}$, whereas the movement of an average refinery from Riverside County to Los Angeles County results in a positive rent of $\$ 263 \mathrm{k}$.

Over time, the $\mathrm{NO}_{\mathrm{X}}$ allocations and rents change as well. In 2000, the allocation to an average Electric Gas and Sanitary Services (SIC 49) facility in Los Angeles County resulted in a positive rent of $\$ 1.5 \mathrm{M}$ as compared to a similar facility in Riverside County. This locationspecific rent translates into $0.5 \%$ of the annual revenue of an average Electric, Gas and Sanitary Services facility in the dataset. Likewise, in the year 2000, the location-specific rent associated with a Petroleum Refining facility in Los Angeles County relative to one in San Bernardino County is $\$ 3.3 \mathrm{M}$. This translates into $0.8 \%$ of an average Petroleum Refining facility's annual revenue.

Over time, the $\mathrm{NO}_{\mathrm{X}}$ allocations and rents change as well. In 2000, the allocation to an average Electric Gas and Sanitary Services (SIC 49) facility in Los Angeles County resulted in a positive rent of $\$ 1.5 \mathrm{M}$ as compared to a similar facility in Riverside County. This locationspecific rent translates into $0.5 \%$ of the annual revenue of an average Electric, Gas and Sanitary Services facility in the dataset. Likewise, in the year 2000, the location-specific rent associated with a Petroleum Refining facility in Los Angeles County relative to one in San Bernardino County is $\$ 3.3 \mathrm{M}$. This translates into $0.8 \%$ of an average Petroleum Refining facility's annual revenue. 
Table 7: Location-specific NOx RECLAIM Trading Credit Allocaitons and Rents for the Electric, Gas and Sanitary Services Industry (SIC 49) in 1994, 2000, and 2003

\begin{tabular}{|c|c|c|c|c|c|}
\hline & \multirow[t]{2}{*}{1994} & \multicolumn{4}{|c|}{ To } \\
\hline & & LAC & $\mathrm{OC}$ & $\mathrm{RC}$ & $\mathrm{SBC}$ \\
\hline \multirow{4}{*}{ 疍 } & LAC & $\begin{array}{r}0 \\
\$ 0\end{array}$ & $\begin{array}{c}-167 \\
(\$ 113,315) \\
\end{array}$ & $\begin{array}{c}-246 \\
(\$ 166,586) \\
\end{array}$ & $\begin{array}{c}-144 \\
(\$ 97,919) \\
\end{array}$ \\
\hline & $\mathrm{OC}$ & $\begin{array}{c}167 \\
\$ 113,315\end{array}$ & $\begin{array}{r}0 \\
\$ 0\end{array}$ & $\begin{array}{c}-79 \\
(\$ 53,271)\end{array}$ & $\begin{array}{c}23 \\
\$ 15,396\end{array}$ \\
\hline & $\mathrm{RC}$ & $\begin{array}{c}246 \\
\$ 166,586\end{array}$ & $\begin{array}{c}79 \\
\$ 53,271\end{array}$ & $\begin{array}{r}0 \\
\$ 0\end{array}$ & $\begin{array}{c}101 \\
\$ 68,666\end{array}$ \\
\hline & SBC & $\begin{array}{c}144 \\
\$ 97,919\end{array}$ & $\begin{array}{c}-23 \\
(\$ 15,396)\end{array}$ & $\begin{array}{c}-101 \\
(\$ 68,666)\end{array}$ & $\begin{array}{r}0 \\
\$ 0\end{array}$ \\
\hline \multirow{6}{*}{ 空 } & 2000 & \multicolumn{4}{|c|}{ To } \\
\hline & & LAC & $\mathrm{OC}$ & $\mathrm{RC}$ & SBC \\
\hline & LAC & $\begin{array}{r}0 \\
\$ 0\end{array}$ & $\begin{array}{c}-35 \\
(\$ 748,453)\end{array}$ & $\begin{array}{c}-68 \\
(\$ 1,456,476)\end{array}$ & $\begin{array}{c}-24 \\
(\$ 508,898)\end{array}$ \\
\hline & $\mathrm{OC}$ & $\begin{array}{c}35 \\
\$ 748,453 \\
\end{array}$ & $\begin{array}{r}0 \\
\$ 0 \\
\end{array}$ & $\begin{array}{c}-33 \\
(\$ 708,022) \\
\end{array}$ & $\begin{array}{c}11 \\
\$ 239,555 \\
\end{array}$ \\
\hline & $\mathrm{RC}$ & $\begin{array}{c}68 \\
\$ 1,456,476\end{array}$ & $\begin{array}{c}33 \\
\$ 708,022\end{array}$ & $\begin{array}{r}0 \\
\$ 0\end{array}$ & $\begin{array}{c}44 \\
\$ 947,577\end{array}$ \\
\hline & SBC & $\begin{array}{c}24 \\
\$ 508,898\end{array}$ & $\begin{array}{c}-11 \\
(\$ 239,555)\end{array}$ & $\begin{array}{c}-44 \\
(\$ 947,577)\end{array}$ & $\begin{array}{r}0 \\
\$ 0\end{array}$ \\
\hline & \multirow[t]{2}{*}{2003} & \multicolumn{4}{|c|}{ To } \\
\hline & & LAC & $\mathrm{OC}$ & $\mathrm{RC}$ & SBC \\
\hline \multirow{4}{*}{ 蛋 } & LAC & $\begin{array}{r}0 \\
\$ 0\end{array}$ & $\begin{array}{c}-27 \\
(\$ 99,974)\end{array}$ & $\begin{array}{c}-51 \\
(\$ 190,446)\end{array}$ & $\begin{array}{c}-18 \\
(\$ 69,364)\end{array}$ \\
\hline & $\mathrm{OC}$ & $\begin{array}{c}27 \\
\$ 99,974 \\
\end{array}$ & $\begin{array}{r}0 \\
\$ 0\end{array}$ & $\begin{array}{c}-24 \\
(\$ 90,472)\end{array}$ & $\begin{array}{c}8 \\
\$ 30,610\end{array}$ \\
\hline & $\mathrm{RC}$ & $\begin{array}{c}51 \\
\$ 190,446 \\
\end{array}$ & $\begin{array}{c}24 \\
\$ 90,472 \\
\end{array}$ & $\begin{array}{r}0 \\
\$ 0 \\
\end{array}$ & $\begin{array}{c}32 \\
\$ 121,082 \\
\end{array}$ \\
\hline & SBC & $\begin{array}{c}18 \\
\$ 69,364\end{array}$ & $\begin{array}{c}-8 \\
(\$ 30,610)\end{array}$ & $\begin{array}{c}-32 \\
(\$ 121,082)\end{array}$ & $\begin{array}{r}0 \\
\$ 0\end{array}$ \\
\hline
\end{tabular}

(C) Southern Regional Science Association 2013. 
Table 8: Location-specific NOx RECLAIM Trading Credit Allocaitons and Rents for the Petroleum Refining Facilities (SIC 29) in 1994, 2000, and 2003

\begin{tabular}{|c|c|c|c|c|c|}
\hline & \multirow[t]{2}{*}{1994} & \multicolumn{4}{|c|}{ To } \\
\hline & & LAC & $\mathrm{OC}$ & $\mathrm{RC}$ & SBC \\
\hline \multirow{4}{*}{ 苛 } & LAC & $\begin{array}{r}0 \\
\$ 0\end{array}$ & $\begin{array}{c}-146 \\
(\$ 99,272)\end{array}$ & $\begin{array}{c}-389 \\
(\$ 263,460)\end{array}$ & $\begin{array}{c}-388 \\
(\$ 262,734)\end{array}$ \\
\hline & OC & $\begin{array}{c}146 \\
\$ 99,272\end{array}$ & $\begin{array}{r}0 \\
\$ 0\end{array}$ & $\begin{array}{c}-242 \\
(\$ 164,188)\end{array}$ & $\begin{array}{c}-241 \\
(\$ 163,461)\end{array}$ \\
\hline & $\mathrm{RC}$ & $\begin{array}{c}389 \\
\$ 263,460\end{array}$ & $\begin{array}{c}242 \\
\$ 164,188\end{array}$ & $\begin{array}{r}0 \\
\$ 0\end{array}$ & $\begin{array}{c}1 \\
\$ 726\end{array}$ \\
\hline & $\mathrm{SBC}$ & $\begin{array}{c}388 \\
\$ 262,734\end{array}$ & $\begin{array}{c}241 \\
\$ 163,461\end{array}$ & $\begin{array}{c}-1 \\
(\$ 726)\end{array}$ & $\begin{array}{r}0 \\
\$ 0\end{array}$ \\
\hline \multirow{6}{*}{ 苛 } & \multirow[t]{2}{*}{2000} & \multicolumn{4}{|c|}{ To } \\
\hline & & LAC & $\mathrm{OC}$ & $\mathrm{RC}$ & SBC \\
\hline & LAC & $\begin{array}{r}0 \\
\$ 0\end{array}$ & $\begin{array}{c}-82 \\
(\$ 1,737,547)\end{array}$ & $\begin{array}{c}-157 \\
(\$ 3,344,834)\end{array}$ & $\begin{array}{c}-157 \\
(\$ 3,349,333)\end{array}$ \\
\hline & OC & $\begin{array}{c}82 \\
\$ 1,737,547\end{array}$ & $\begin{array}{r}0 \\
\$ 0\end{array}$ & $\begin{array}{c}-75 \\
(\$ 1,607,287)\end{array}$ & $\begin{array}{c}-76 \\
(\$ 1,611,787)\end{array}$ \\
\hline & $\mathrm{RC}$ & $\begin{array}{c}157 \\
\$ 3,344,834\end{array}$ & $\begin{array}{c}75 \\
\$ 1,607,287\end{array}$ & $\begin{array}{r}0 \\
\$ 0\end{array}$ & $\begin{array}{c}-0.2 \\
(\$ 4,500)\end{array}$ \\
\hline & SBC & $\begin{array}{c}157 \\
\$ 3,349,333\end{array}$ & $\begin{array}{c}76 \\
\$ 1,611,787\end{array}$ & $\begin{array}{c}0.2 \\
\$ 4,500\end{array}$ & $\begin{array}{r}0 \\
\$ 0\end{array}$ \\
\hline & \multirow[t]{2}{*}{2003} & \multicolumn{4}{|c|}{ To } \\
\hline & & LAC & $\mathrm{OC}$ & $\mathrm{RC}$ & SBC \\
\hline \multirow{4}{*}{ 疍 } & LAC & $\begin{array}{r}0 \\
\$ 0\end{array}$ & $\begin{array}{c}-59 \\
(\$ 222,513)\end{array}$ & $\begin{array}{c}-114 \\
(\$ 427,891)\end{array}$ & $\begin{array}{c}-114 \\
(\$ 428,468)\end{array}$ \\
\hline & $\mathrm{OC}$ & $\begin{array}{c}59 \\
\$ 222,513 \\
\end{array}$ & $\begin{array}{r}0 \\
\$ 0 \\
\end{array}$ & $\begin{array}{c}-55 \\
(\$ 205,377) \\
\end{array}$ & $\begin{array}{c}-55 \\
(\$ 205,954) \\
\end{array}$ \\
\hline & $\mathrm{RC}$ & $\begin{array}{c}114 \\
\$ 427,891\end{array}$ & $\begin{array}{c}55 \\
\$ 205,377\end{array}$ & $\begin{array}{r}0 \\
\$ 0\end{array}$ & $\begin{array}{c}-0.2 \\
(\$ 577)\end{array}$ \\
\hline & $\mathrm{SBC}$ & $\begin{array}{c}114 \\
\$ 428,468\end{array}$ & $\begin{array}{c}55 \\
\$ 205,954\end{array}$ & $\begin{array}{c}0.2 \\
\$ 577\end{array}$ & $\begin{array}{r}0 \\
\$ 0\end{array}$ \\
\hline
\end{tabular}

\section{CONCLUSIONS}

This paper examined the factors that may influence the allocation of tradable $\mathrm{NO}_{\mathrm{X}}$ credits and its deviations from historical emissions under the RECLAIM program. Our empirical results confirm that the employment to $\mathrm{NO}_{\mathrm{X}}$ ratio, and the size of the firm impact the deviations in $\mathrm{NO}_{\mathrm{X}}$ credit allocations between the historical emissions levels and the 1994, 2000, and 2003 allocation levels, and that the toxics to $\mathrm{NO}_{\mathrm{X}}$ ratio impacts the deviations in NOx credit allocations between 
the historical emissions level and the 1994 allocation level. In addition, our empirical work suggests that the location of the facility impacts the deviations in credit allocations.

The spatially disaggregate nature of our analysis allows us to consider the potential for hot spots of $\mathrm{NO}_{\mathrm{X}}$ and toxics that may emerge as a result of the geographical concentration of facilities. A surprising finding is that regulators used the RECLAIM program-which was designed to regulate $\mathrm{NO}_{\mathrm{X}}$ and $\mathrm{SO}_{\mathrm{X}}$ - to also regulate toxics, perhaps in response to pressure from environmental justice lobbies or simply the inability to regulate toxics directly. This is remarkable because in the absence of trade, a cap and trade framework degrades to a simple command-and-control regime, and therefore, at least in the initial years of the RECLAIM program, it appears that regulators may have indeed succeeded in reducing toxic hotspots. Not surprisingly, over time, with increased trade and the installation of abatement technologies, the regulator loses their ability to influence toxic emissions through the credit allocation rule. One of the significant implications of this outcome is in the design of market-based cap and trade systems that involve the delegation of management and oversight to local, publicly-elected officials. Specifically, the benefits of having a regulatory body that is in much closer proximity to the regulated industries may also result in outcomes that are contrary to the mission of the regulation itself. In the case of the RECLAIM program we find the potential for the regulation of pollutants that aren't identified in the legislation itself.

We also find that, at least in the initial years of the program, regulators protected specific industrial groups within the SCAQMD. This result reinforces the findings of the acid rain program by Joskow and Schmalensee (1998), where the authors also found that the electricity industry was initially protected given the extremely high costs of installation of scrubbers and new burners.

At first glance, the total deviation in credit allocations between the historical emission level and the 1994 allocation level may appear to be small when compared to the total pollution emissions within the SCAQMD. ${ }^{36}$ However, the $\mathrm{NO}_{\mathrm{X}}$ credit backstop price which was set at $\$ 15 \mathrm{k} / \mathrm{NO}_{\mathrm{X}}$-ton at the outset of the RELCAIM program, and was reached during the California electricity crisis of 2000-2001, would translate into a net welfare transfer of $\$ 271 \mathrm{M}^{37}$ The average per-facility underallocation of $\mathrm{NO}_{\mathrm{X}}$ credits is small when compared to some of the emission levels of the larger companies in the SCAQMD, but is sizeable for many of the smaller polluting firms in the SCAQMD. On average, the deviation between the historical emission level and the 1994 allocation was 48.4 tons of $\mathrm{NO}_{\mathrm{X}}$ credits per facility. At the backstop price of $\$ 15 \mathrm{k} /$ $\mathrm{NO}_{\mathrm{X}}$-ton, this translates into just over $\$ 725 \mathrm{k}$ per firm. Therefore the deviations from the historical rule that are introduced by the local regulatory agency have the potential of resulting in significant revenue reallocations.

It would be inadvisable to interpret our results without some notable caveats. Although a firm-level analysis is most desirable in attempting to disentangle the discretionary influences that regulators may exert on individual firms, there is a paucity of firm-level data, and thus we were forced to make some assumptions on our employment and revenue estimates. The program itself does encompass the largest polluting facilities in the area-facilities that likely represent a

\footnotetext{
${ }^{36}$ The total deviation between the historical emission level and the 1994 allocation level was approximately 18,086 tons of $\mathrm{NO}_{\mathrm{X}}$ credits. The total $\mathrm{NO}_{\mathrm{X}}$ credit allocation in 1994 was 36,781 tons of $\mathrm{NO}_{\mathrm{X}}$ credits.

${ }^{37} \mathrm{The} \$ 15 \mathrm{k} / \mathrm{NO}_{\mathrm{X}}$-ton backstop price was established in SCAQMD rule 2015-Backstop Provisions.
} 
majority of the emissions attributable to those SIC categories that they represent. In this case one might argue, as we have, that it is reasonable to assume that state level (four-digit) SIC employment and revenue averages are reflective of those same industries in the SCAQMD. Nevertheless, assumptions have still been made.

Similarly, the employment and revenue effects of firm-level influences should not be expected to end at the sociopolitical borders of the SCAQMD. Regulatory impacts to large corporations in the SCAQMD will impact employment and revenue measures across the state as the non-SCAQMD subsidiaries that are physically located outside of the SCAQMD will be impacted. In this case, the use of facility-only data may underestimate the true employment and fiscal impacts of regulatory decision making, and therefore region- or state-level average employment and revenue figures may be more reflective of the true economy-wide impacts of regulatory discretionary power. Regardless, we feel that this is a first step toward better understanding the potential impacts that including discretionary power in market-based permit systems may introduce.

\section{REFERENCES}

Anselin, Luc. (1988) Spatial Econometrics: Methods and Models. Kluwer Academic Publishers: Dordecht, The Netherlands.

Atkinson, Scott E. and Donald H. Lewis. (1974) "A Cost-Effective Analysis of Alternative Air Control Strategies," Journal of Environmental Economics and Management, 1, 237-250.

Baumol, William J. and Wallace E. Oates. (1971) "The Use of Standards and Prices for Protection of the Environment," Swedish Journal of Economics, 73, 42-54.

Berman, Eli and Linda T. M. Bui. (2001) "Environmental Regulation and Labor Demand: Evidence from the South Coast Air Basin,” Journal of Public Economics, 79, 265-295.

Bovenberg, A. Lans, Larry H. Goulder, and Derek J. Gurney. (2005) "Efficiency Costs of Meeting Industry-Distributional Constraints under Environmental Permits and Taxes," RAND Journal of Economics, 36, 950-970

Bovenberg, A. Lans, Larry H. Goulder, and Mark R. Jacobsen. (2008) "Costs of Alternative Environmental Policy Instruments in the Presence of Industry Compensation Requirements," Journal of Public Economics, 92, 1236-1253

California Health and Safety Code. (2006). South Coast Air Quality Management District Governing Body, Chapter 5.5, Article 3, Sections 40420-40422.

Cliff, Andrew D. and John K. Ord. (1973) Spatial Autocorrelation. Pion Publishers: London.

Cone, Maria (1993) "Smog Market Set to Open in Southland," Los Angeles Times, December 28.

Conley, Timothy G. (1999) “GMM Estimation with Cross-sectional Dependence," Journal of Econometrics, 92, 1-45.

Cook, Brian J. (2010) "Arenas of Power in Climate Change Policymaking," Policy Studies Journal, 38, 465-486.

Cropper, Maureen, William N. Evans, Steve Berard, Maria Soares, and Paul Portney. (1992) “An Analysis of EPA Regulation of Food-Use Pesticides," Journal of Political Economy, 100, 175-197.

(C) Southern Regional Science Association 2013. 
Dales, John H. (1968) Pollution, Property \& Prices, University of Toronto Press: Toronto.

da Mata, Daniel, Uwe Deichmann, J. Vernon Henderson, Somik V. Lall, and Hyoung Gun Wang. (2005) "Determinants of City Growth in Brazil," NBER Working Paper No. 11585 .

Ellerman, A. Denny, Barbara K. Buchner, and Carlo Carraro. (2007) Allocation in the European Emissions Trading Scheme. Cambridge University Press: Cambridge, UK.

Fowlie, Meredith and Jeffrey M. Perloff. (2008) "Distributing Pollution Rights in Cap-and-Trade Programs: Are Outcomes Independent of Allocation?," CUDARE Working Paper Series 0968R, Department of Agricultural \& Resource Economics, University of California at Berkeley.

Fowlie, Meredith, Stephen P. Holland, and Erin T. Mansur. (2012) "What Do Emissions Markets Deliver and to Whom? Evidence from Southern California's $\mathrm{NO}_{\mathrm{X}}$ Trading Program," American Economic Review, 102, 965-993.

Gangadharan, Lata. (2000) "Transactions Costs in Pollution Markets: An Empirical Study," Land Economics, 76, 601-614.

Hahn, Robert W. and Gordon L. Hester. (1989) "Marketable Permits: Lessons from Theory and Practice," Ecology Law Quarterly, 16, 361-406.

Hahn, Robert W. and Robert N. Stavins. (2011) "The Effect of Allowance Allocations on Capand-Trade System Performance," Journal of Law and Economics, 54, 267-294.

Johnson, Scott L. and David M. Pekelney. (1996) "Economic Assessment of the Regional Clean Air Incentives Market: A New Emissions Trading Program for Los Angeles," Land Economics, 72, 277-297.

Joskow, Paul L. and Richard Schmalensee. (1998) "The Political Economy of Market-based Environmental policy: The U.S. Acid Rain Program," Journal of Law and Economics, $41,37-84$.

Kosobud, Richard F., Houston H. Stokes, and Carol D. Tallarico. (2004) "Does Emissions Trading Lead to Air Pollution Hot Spots? Evidence from an Urban Ozone Control Programme," International Journal of Environmental Technology and Management, 4, $137-156$.

Kosobud, Richard F., Joshua Linn, Houston H. Stokes, and Carol D. Tallarico. (2008) "Regulatory Conflict in the Chicago VOC Control Program," Journal of Environmental Planning and Management, 51, 561-579.

McGartland, Albert M. and Wallace E. Oates. (1985) "Marketable Permits for the Prevention of Environmental Deterioration," Journal of Environmental Economics and Management, $12,207-228$

Montgomery, W. David. (1972) "Markets in Licenses and Efficient Pollution Control Programs," Journal of Economic Theory, 5, 395-418.

Morgenstern, Richard D., William A. Pizer, and Jhih-Shyang Shih. (2002) "Jobs versus the Environment: An Industry-level Perspective," Journal of Environmental Economics and Management, 43, 412-436.

(C) Southern Regional Science Association 2013. 
Oates, Wallace E. and Paul R. Portney. (2003) "The Political Economy of Environmental Policy," Chapter 8 in Karl-Göran Mäler and Jeffrey R. Vincent (eds.), Handbook of Environmental Economics, Volume 1. Elsevier-North Holland: Amsterdam, pp. 325-354.

Peters, John M., Edward Avol, William Navidi, Stephanie J. London, W. James Gauderman, Fred Lurmann, William S. Linn, Helene Margolis, Edward Rappaport, Henry Gong, and Duncan C. Thomas. (1999) "A Study of Twelve Southern California Communities with Differing Levels and Types of Air Pollution: Prevalence of Respiratory Morbidity," American Journal of Respiratory Critical Care Medicine, 159, 760-767.

Prager, Michael A., Thomas H. Klier, Rick H. Mattoon. (1996). “A Mixed Bag: Assessment of Market Performance and Firm Trading Behavior in the $\mathrm{NO}_{\mathrm{X}}$ RECLAIM Program," Federal Reserve Bank of Chicago Working Papers Series (WP-96-12).

Rabe, Barry G. (2010) “The Aversion to Direct Cost Imposition: Selecting Climate Policy Tools in the United States," Governance, 23, 583-608.

Rappaport, Jordan and Jeffrey D. Sachs. (2001) “The U.S. as a Coastal Nation," Federal Reserve Bank of Kansas City Research Working Paper No. 01-11.

Raymond, Leigh S. (2003) Private Rights in Public Resources: Equity and Property Allocation in Market-Based Environmental Policy, RFF Press: Washington, D.C.

Schubert, Uwe and Andreas Zerlauth. (1999) "Innovative Regional Environmental Policy-the RECLAIM Emission Trading Policy," Environmental Management and Health, 10, 130142.

Seskin, Eugene P., Robert J. Anderson, Jr., and Robert O. Reid. (1983) “An Empirical Analysis of Economic Strategies for Controlling Air Pollution," Journal of Environmental Economics and Management, 10, 112-124.

Sigman, Hilary. (2001) "The Pace of Progress at Superfund Sites: Policy Goals and Interest Group Influence," Journal of Law and Economics, 44, 315-344.

Solomon, Barry D. and Russel Lee. (2000) "Emissions Trading Systems and Environmental Justice," Environment, 42(8), 32-45.

South Coast Air Quality Management District. (1993a) Rule 2001-Applicability.

. (1993b) Rule 2002-Allocations for Oxides of Nitrogen $\left(N O_{X}\right)$ and Oxides of Sulfur $\left(S O_{X}\right)$.

. (1998) Stationary Source Compliance Committee, Annual RECLAIM Audit Report for the 1996 Compliance Year.

. (2000a) Multiple air toxics exposure study in the South Coast Air Basin: MATES-II Final report (and appendices), March.

. (2000b) Office of Engineering and Compliance, Review of RECLAIM Findings.

. (2006). Historic Ozone Air Quality Trends.

. (2008). About the South Coast Air Quality Management District.

Stavins, Robert N. (1995) "Transaction Costs and Tradeable Permits," Journal of Environmental Economics and Management, 29, 133-148.

(C) Southern Regional Science Association 2013. 
. (2004) The Political Economy of Environmental Regulations. Edward Elgar Publishing Northampton, MA.

Superior Court of California, County of Los Angeles. (1993) The Alliance of Small Emitters, Etc. Vs. S. Coast Air Quality, Case Number BC094283.

Tietenberg, Tom H. (1990) "Economic Instruments for Environmental Regulation," Oxford Review of Economic Policy, 6, 17-33.

. (2006) Emissions Trading: Principles and Practice. Resources for the Future Press: Washington, D.C.

U.S. Environmental Protection Agency. (1995) Approval and Promulgation of Implementation Plans; California Implementation Plan Revision; South Coast Air Quality Management District. February $28^{\text {th }}$.

. (2001) The United States Experience with Economic Incentives for Pollution Control.

. (2002) EPA's Evaluation of the RECLAIM Program in the South Coast Air Quality Management District. November.

. (2006) An Overview of the Regional Clean Air Incentives Market (RECLAIM), EPA Clean Air Markets Division.

Weitzman, Martin L. (1974) “Prices vs. Quantities,” Review of Economic Studies, 41, 477-491

(C) Southern Regional Science Association 2013. 